\title{
Electrocatalytic oxidation of tyrosines shows signal enhancement in label-free protein biosensors
}

\author{
Ming-Yuan Wei, Liang-Hong Guo, Parviz Famouri
}

Label-free electrochemical (EC) protein biosensors that derive electrical signal from redox-active amino acid (AA) residues can avoid disruption of delicate protein structures, and thus provide a great opportunity to reveal valid information about protein functions. However, the challenge is that such a signal is usually very limited due to the sluggish EC reaction of free AAs on most common electrodes and slow electron-transfer rates from the deeply-buried AA residues in a protein to the electrode. Signal enhancement therefore becomes crucial. We first survey recent progress in this area.

We present a signal-enhancing system that relies on the electrocatalytic oxidation of tyrosine mediated by osmium bipyridine or phenoxazine complexes. We describe several applications of label-free protein EC biosensors based on this detection principle for the analysis of protein functions, including the monitoring of protein-conformation change, study of ligand/protein binding, and detection of protein oxidative damage and protein phosphorylation.

We describe related works on protein-function analysis using other signal-enhancing methods. The results suggest that labelfree EC protein biosensors are suitable for the rapid survey of protein functions due to their fast response, ease of integration, cost effectiveness and convenience. Proof-of-concept work on the application of our system is paving the way for bio-analytical detections and protein-function analysis in future work.

(c) 2012 Elsevier Ltd. All rights reserved.

Keywords: Bioanalytical detection; Biosensor; Electrocatalytic oxidation; Electrochemistry; Label-free protein biosensor; Osmium bipyridine; Phenoxazine; Signal enhancement; Protein function; Tyrosine

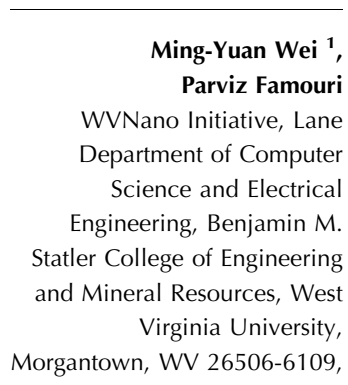

USA

Liang-Hong Guo*

State Key Laboratory of Environmental Chemistry and Ecotoxicology, Research Center for Eco-environmental Sciences, Chinese Academy of Sciences, Beijing 100085,

China

${ }^{1}$ Current address: Department of Bioenginnering, University of Texas at Arlington, 500 UTA Blvd., Arlington, TX 76010, USA ${ }^{*}$ Corresponding author. Tel./Fax: +86 10 62849685; E-mail: Ihguo@rcees.ac.cn

\section{Introduction}

Proteins are not only one of the main building blocks of cells, but also responsible for nearly all cell functions [1]. Proteins can serve as enzymes to catalyze chemical reactions. Antibodies are able to recognize and to bind with foreign substrates (e.g. bacteria or viruses), so as to target them for destruction. Plasmatransport proteins bind to particular small molecules and transport them to other locations where they are needed (e.g., oxygen is transported by hemoglobin from the lungs to other organs and tissues). Some membrane proteins pump ions across the membrane e.g., $\mathrm{Ca}^{2+}$ pump [2]\}, while others act as "receptors" [3] that bind to signaling molecules on the cell surface and induce biochemical response inside the cell. Such signaling responses within cells often depend on protein modifications, namely post-translational modifications (PTMs) [4-8], in which chemical functional groups (e.g., phosphate, acetate, carbohydrate) are covalently attached to protein amino-acid (AA) residues under the action of enzymes \{e.g., signaling can be turned "ON" in terms of protein phosphorylation by protein kinases [9], and switched "OFF" as dephosphorylation by phosphatases\}. For muscle stretch, motor proteins conduct movement via changing conformation in the presence of ATP (e.g., myosion/actin filament) $[10,11]$.

Proteomics involves large-scale study to identify proteins and reveal their functions [12]. Sophisticated methods have been developed for protein sequencing and structure identification [e.g., 2D electrophoresis, electrospray ionization or matrix-assisted laser desorption/ionization mass spectrometry (EI-MS or MALDI-MS), X-ray crystallography, and nuclear magnetic resonance (NMR) spectroscopy]. However, it is extremely intriguing to pursue the goal of functional proteomics 
that directly interprets information about protein functions. In general, such function analysis can be conducted by a large variety of biochemical and cellular assays. Considered rapid and cost effective at the molecular level, protein biosensors have been emerging as a new generation of detectors for protein-function analysis.

A biosensor is defined as "a self-contained integrated device, which is capable of providing specific quantitative or semi-quantitative analytical information using a biological recognition element (biochemical receptor) that is retained in direct spatial contact with a transduction element [13]." A protein biosensor uses protein as the sensing element for quantitative detection and function analysis \{e.g., enzyme biosensors or immunosensors (antibody biosensors) can detect and quantify the molecule of interest (e.g., glucose, virus, or environmental pollutant)\}. However, in this review, we focus on those protein biosensors designed for function analysis (e.g., investigating protein functions upon conformation change, ligand binding, and PTM). Findings in these areas shed light on diagnosis and therapy of fatal human diseases $\{$ e.g., cancer $[4-6,14]\}$ or neurodegenerative diseases \{e.g., Alzheimer's or Parkinson's) $[7,8]$ \} .

Based on the nature of signal read-out, protein biosensors can be classified into three general categories [15-18]: optical (e.g., absorbance, fluorescence, luminescence, or surface-plasmon resonance); electrochemical (EC); and, mass-based (e.g., quartz crystal microbalance). Among them, the EC protein biosensor is recognized as rapid, low cost and convenient. It is more suitable to configure into integrated portable devices due to the lack of complicated optical components and alignment that optical biosensors have to rely on. A wellknown example of commercially successful EC protein biosensor is the glucose meter for the routine monitoring of blood-glucose level of diabetic patients [19].

Regarding signal generation, EC protein biosensors can monitor electrical signal from electro-active labels attached to proteins \{e.g., metal complexes (ferrocene [20-26], ruthenium complex [27,28]), or metal nanoparticles [29-31]\}. Apparently, its disadvantages are the requirement for complex procedures for protein labeling, and purification and characterization of the protein-label

Table 1. Summary of selected optical and redox-active amino acids that are frequently used in literature

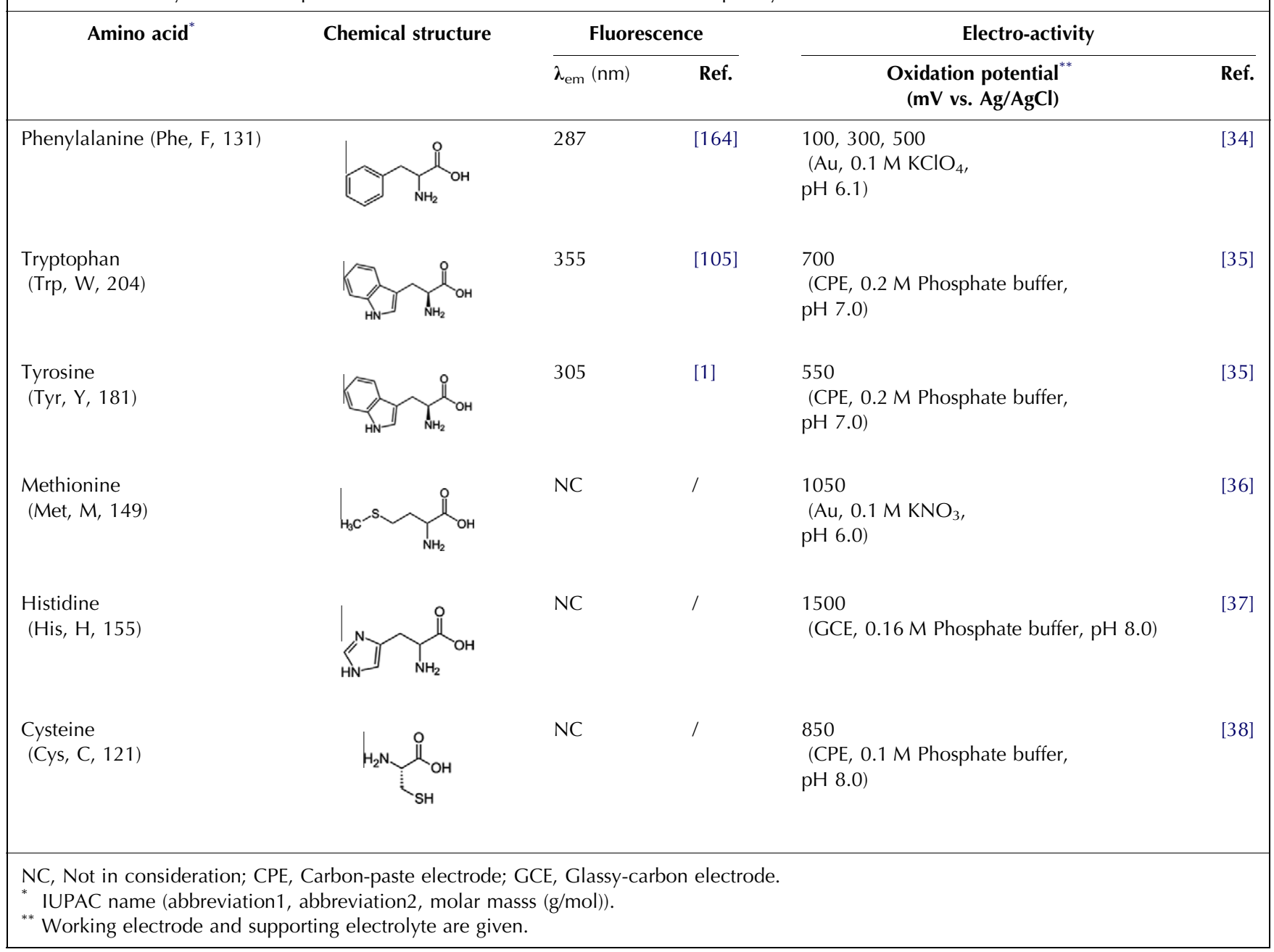




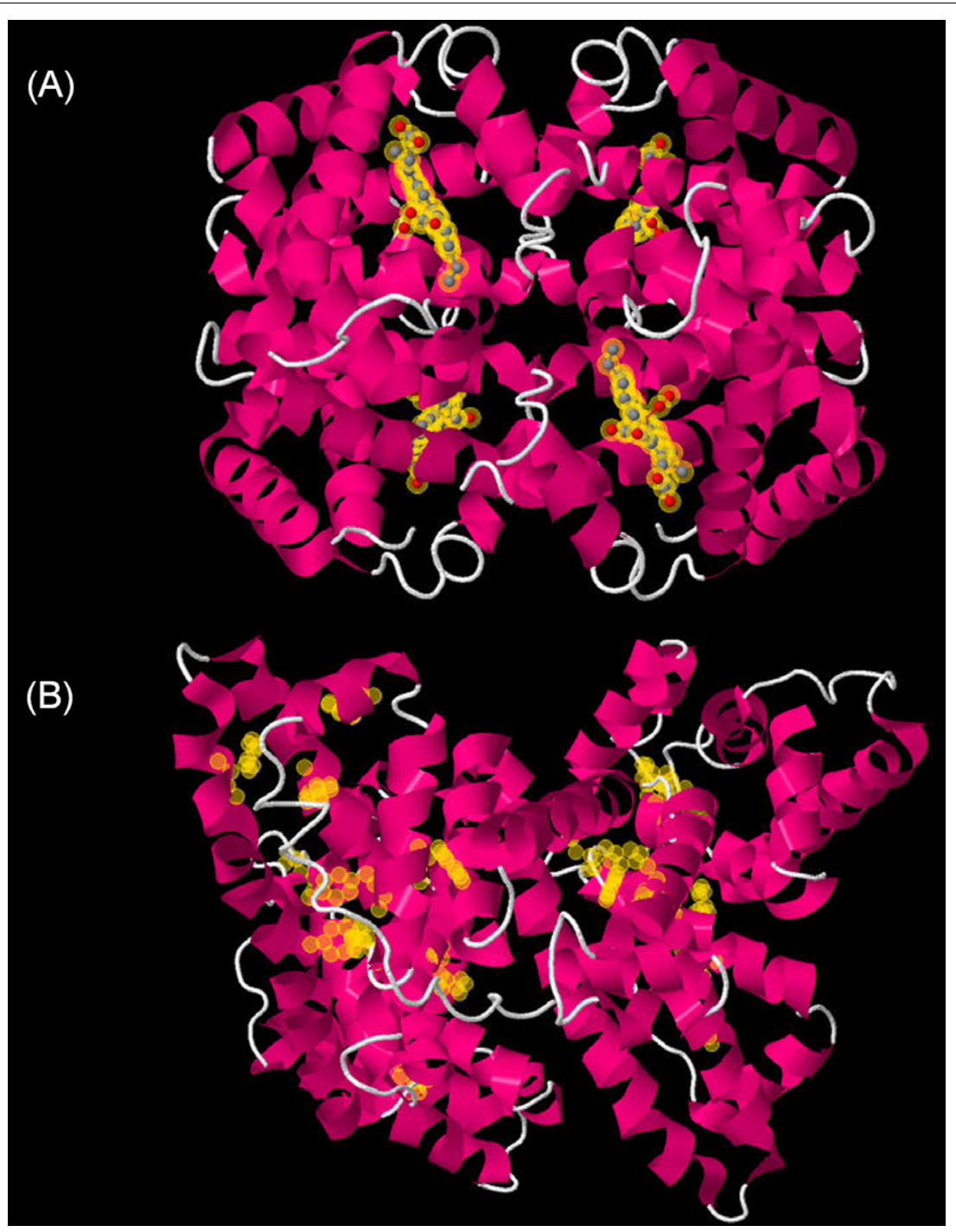

Figure 1. Three-dimensional structures of (A) human oxyhemoglobin (ID: $1 \mathrm{HHO}$ ) and (B) human serum albumin (ID: $1 \mathrm{AO6})$. Heme groups in (A) or tyrosine residues in (B) are marked with yellow haloes. Crystal structures are demonstrated with JMOL (Version 12.0.41), from RCSB Protein Data Bank (http://www.rcsb.org/pdb/home/home.do).

conjugate. More importantly, these procedures may disrupt protein structures. As an alternative, label-free EC protein biosensors rely on the intrinsic signal from redox-active co-factors \{e.g., heme groups (Fig. 1A)\}, flavin adenine dinucleotide, or some AA residues that are electrochemically active $\{$ e.g., tyrosine (Tyr), tryptophan (Trp) and cysteine (Cys) $\}$.

Table 1 gives more information about EC oxidation of these AAs, about which there are useful review articles [32-38]). In this way, protein structure can stay intact so that valid information about protein functions can be obtained.

Several challenges still remain in the application of label-free EC protein biosensors. First, only a minority of proteins contains redox-active co-factors that may provide a detection signal (e.g., cytochromes, blue-copper proteins, iron-sulfur proteins, and flavodoxins). For the majority of proteins, signal generation has to rely on redox-active AA residues, as summarized in Table 1 . However, EC reaction of these AAs is quite sluggish on most common electrodes, leading to limited EC signal [32,33]. Second, most co-factors and many electro-active AA residues are likely to be buried in the internal cavities of proteins (Fig. 1 marked as yellow halos). The electrontransfer (ET) rate from the redox group to the electrode is therefore very slow due to the long distance [39]. This further lowers the signal response. Another complication is that electrode fouling/passivation might occur by protein adsorption $[32,40]$ or formation of oxidized products and decomposition of AAs on the electrode surface [41,42].

Many strategies have been devised to overcome the above-mentioned problems, as summarized in Table 2 . Signal enhancement based on electrocatalytic oxidation of 


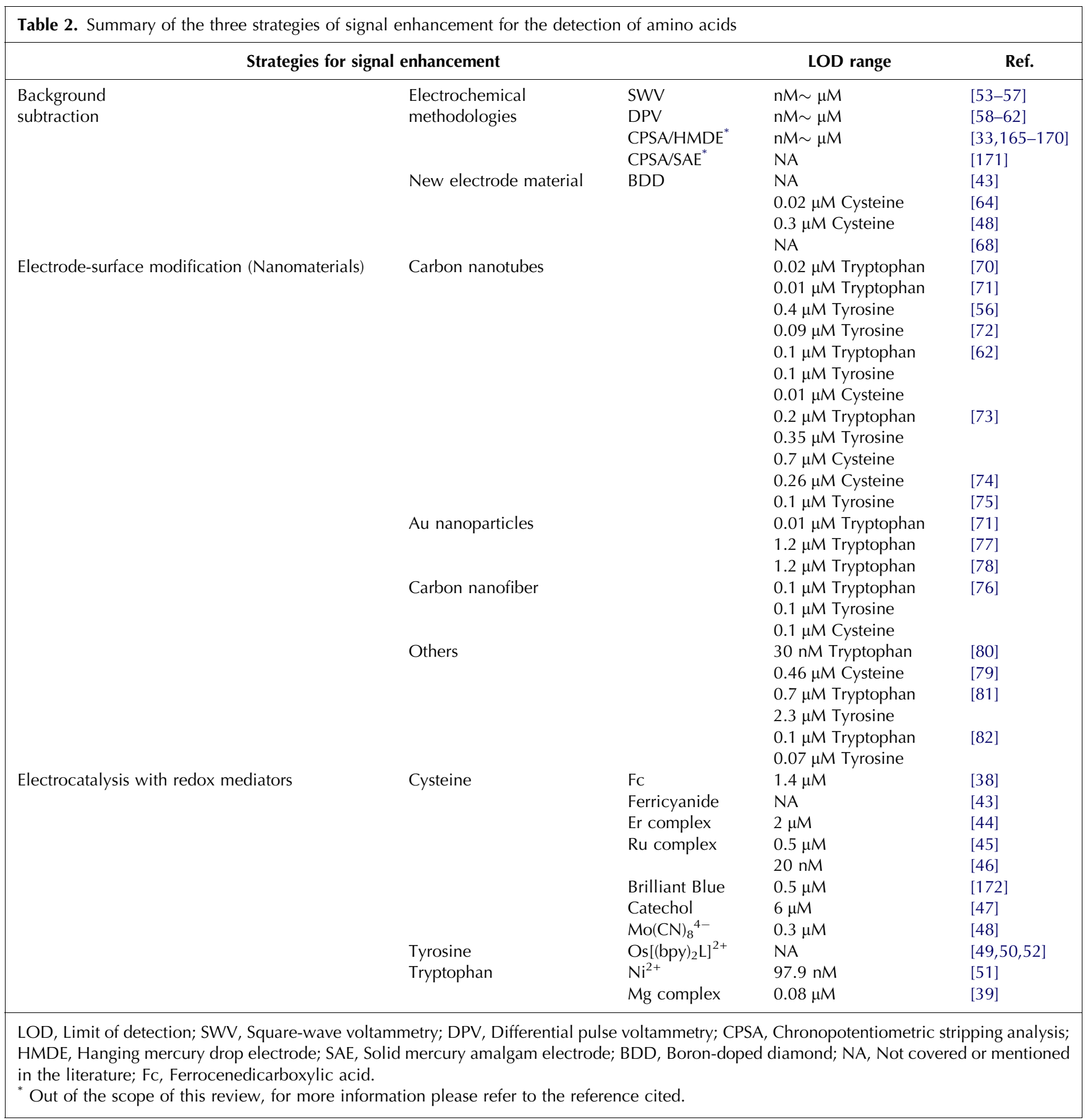

Tyr, Trp and Cys has been reported [38,39,43-52]. Signal-to-background ratio can be improved by employing square-wave voltammetry (SWV) [53-57] and differential pulse voltammetry (DPV) [58-62], which minimize the background current from capacitive charging in EC analysis.

New electrode materials [i.e. boron-doped diamond (BDD) electrodes] excel in a wide potential window (-3$\sim 3.75 \mathrm{~V}$ ) and chemical inertness [63]. The unique properties lead to low background current and resistance to electrode fouling by protein adsorption, making the BDD electrode a great substrate for protein analysis [64-68].

Nanomaterial-based electrodes have demonstrated fascinating capabilities in EC catalysis with reduced overpotential and improved EC reversibility for many chemical species ([69] and references therein). As shown in Scheme 1A, detection of AAs has been reported on electrodes modified with carbon nanotubes (CNTs) [56,62,70-75], carbon nanofiber (CNF) [76], Au nanoparticles (AuNPs) $[71,77,78]$, and other nanomaterials 
(A)
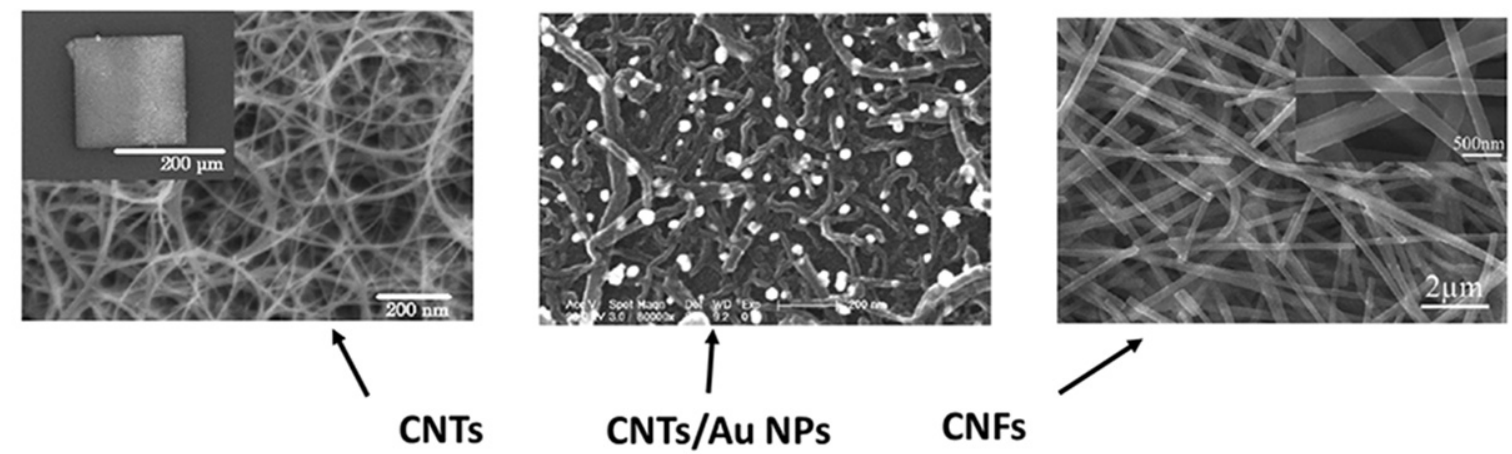

CNTs/Au NPs CNFs

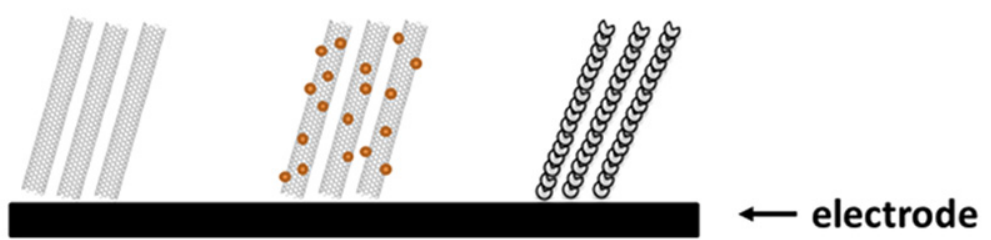

(B)
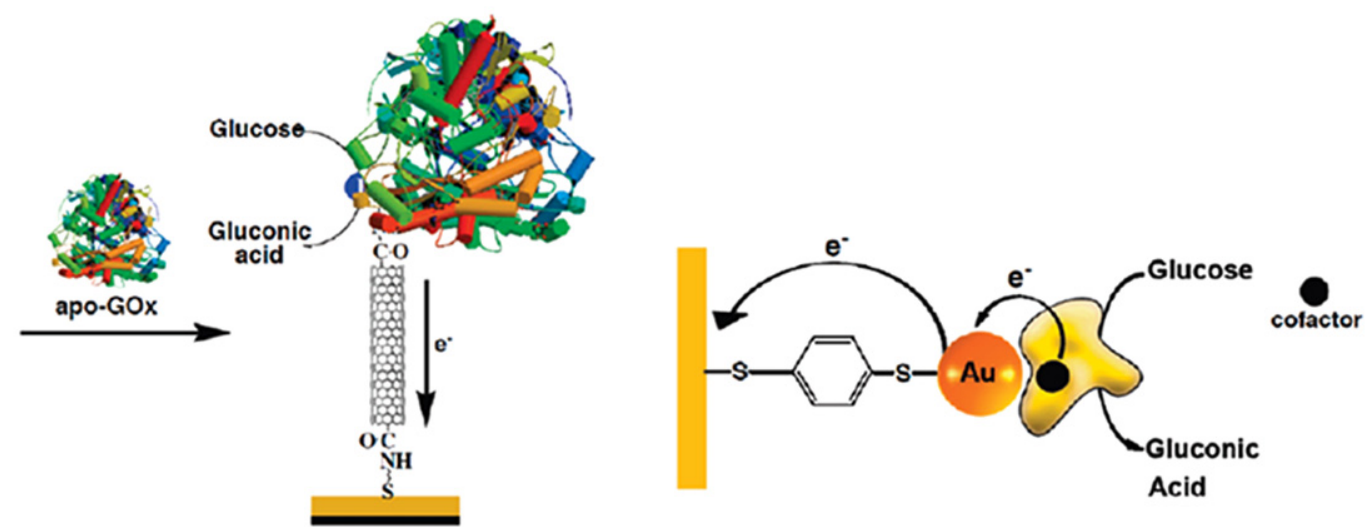

Scheme 1. (A) Electrode modification with nanomaterial. (TEM images are adapted from $[62,71,76]$ with permission, (@2007 and @ 2010 , Elsevier BV). (B) Nanomaterials as electron connector (Adapted from [86] with permission, @2010, American Chemical Society).

[79-82]. Simultaneous determination of multiple AAs (3-4) in one sample was achieved on CNTs, which can be attributed to the catalysis at the graphitic edge-plane sites at the exposed ends of the CNT [83-85].

Conductive nanomaterials can also enhance EC signal by shuttling/wiring electrons over long distances in proteins [86] \{e.g., AuNPs [87] and CNTs [88] were used as electron connectors to electrically wire the redox co-factor of glucose oxidase to the electrode, thus greatly enhancing the bioelectrocatalytic oxidation of glucose (Scheme 1B)\}.

In this brief review, we survey recent progress in the investigation of protein functions using label-free EC protein biosensors, with a focus on biosensors based on signal enhancement from electrocatalytic oxidation of Tyr. We present a range of protein-function analyses in the following section \{e.g., monitoring protein-conformation change [52], investigation of protein-ligand interaction [89], detection of oxidative damage of proteins [90], and detection of protein phosphorylation $[91,92]\}$. We also survey and discuss related works involving signal enhancement in these fields. This review showcases what electroanalytical chemistry would be expected to contribute in proteomics. Label-free EC protein biosensors provide a valuable tool for the analysis of protein functions and elucidation of the relationship between protein structure and functions. Coupled with this new knowledge, protein biosensors can be further developed into small devices, or even micro/nano implantable sensors, which satisfy the needs of in situ and point-of-care medical diagnosis.

\section{Basic work: electrocatalytic oxidation of tyrosine}

Proteins have been a favorite subject of electrochemists for the past few decades. In the first reports on the direct electrochemistry (without any mediator) of redox 


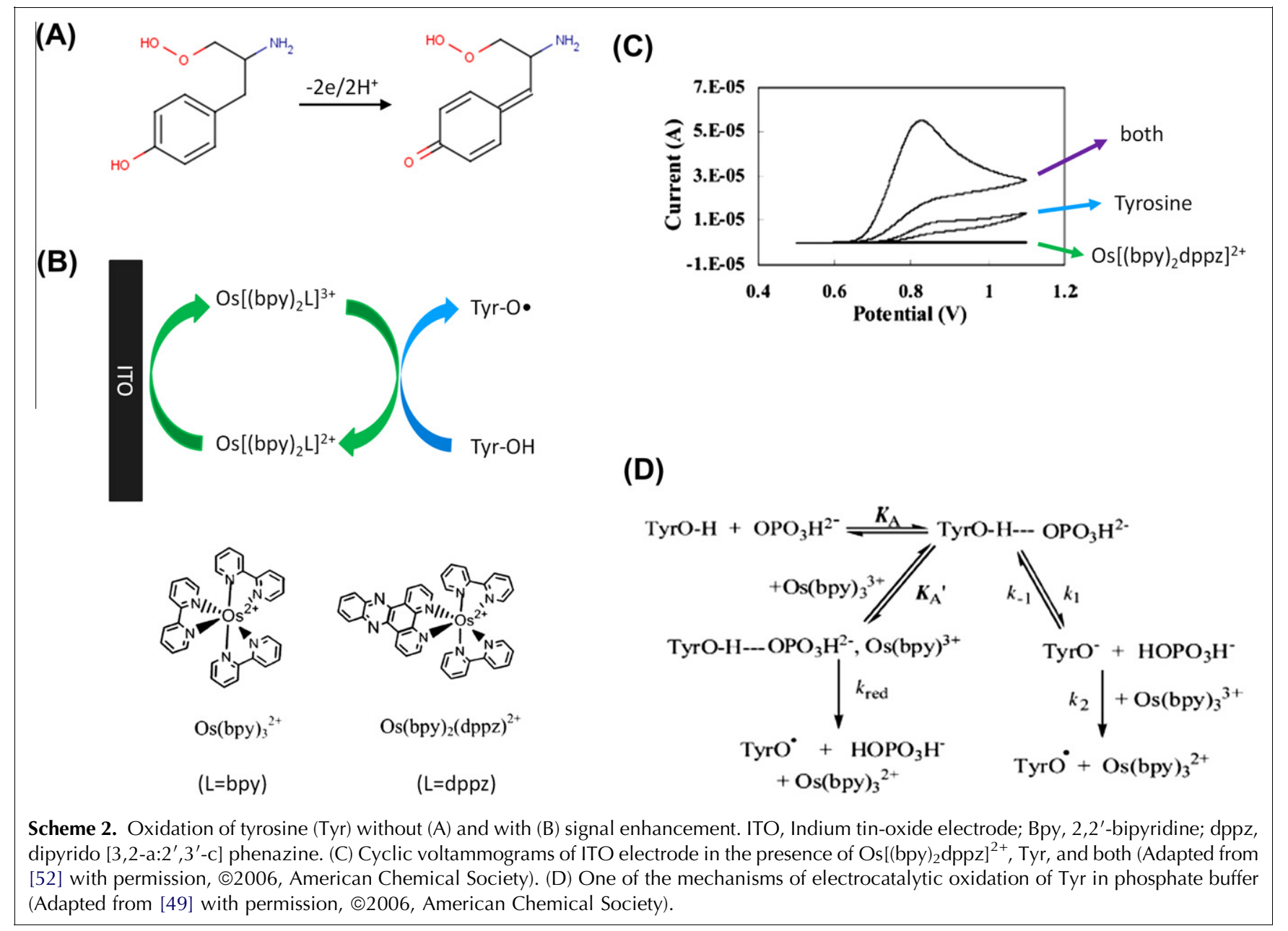

proteins, which were published in 1977 [93,94], the cofactor, heme, of cytochrome $c$ is the contributor to its electroactivity. However, the majority of proteins lack co-factors, so that label-free EC detection often relies on redox-active AAs (e.g., Tyr, Cys, and Trp) (Table 1). The EC activity of AAs, first discovered in 1980 [95,96], showed that Tyr and Trp were oxidized on carbon electrodes. The process of Tyr oxidation was considered a two electron/two proton transfer oxidation $[17,72,96-$ 98] (Scheme 2A). Others also observed Tyr oxidation in terms of one electron/one proton transfer [33,56,99]. In either case, signal response was often low due to the irreversibility of Tyr's electrode reaction. The oxidation of Tyr residues in a protein is further suppressed [52,89], since they are likely to be buried in the internal cavities of a protein molecule [e.g., human serum albumin (HSA, in Fig. 1B)].

Our group developed a signal-enhancing system [52,89-92] based on the electrocatalytic oxidation of Tyr on indium tin oxide (ITO) electrode, using osmium polypyridine complexes as redox mediators (Scheme 2B). Tyr was chosen as the intrinsic signal reporter due to its lowest oxidation potential of $0.55 \mathrm{~V}$ [35] compared with other redox-active AA residues (Table 1). This permits the selective oxidation of Tyr in the presence of other AAs when a mediator with appropriate oxidation potential is employed.

Two types of $\mathrm{Os}(\mathrm{bpy})_{2} \mathrm{~L}^{2+}$ complexes were employed as redox mediator in our signal-enhancing system, in which L is either bpy or dppz (bpy $=2,2^{\prime}$-bipyridine, $\mathrm{dppz}=$ dipyrido $\left[3,2-\mathrm{a}: 2^{\prime}, 3^{\prime}-\mathrm{c}\right]$ phenazine $)$. Os $(\mathrm{bpy})_{2} \mathrm{~L}^{2+}$ complexes are chemically stable, and show reversible EC response on the ITO electrode. Their oxidation potential is high enough to oxidize Tyr, and can be finetuned easily by changing the ligands $[100,101]$. ITO was selected as the working electrode because it has a wide potential window (up to $2 \mathrm{~V}$ ), and the background current from direct Tyr oxidation is very low. Its surface is hydrophilic and therefore unfavorable for nonspecific protein adsorption. In addition, the hydroxyl groups on the ITO surface allow surface modification through silanization and subsequent protein immobilization.

The mechanism of signal enhancement involves EC oxidation of the mediator $\mathrm{M}$ to $\mathrm{M}^{+}$on the ITO electrode, followed by a chemical reaction between $\mathrm{M}^{+}$and Tyr to 
produce $M$ and oxidized Tyr [Equations (1) and (2)]. Because this is a classical electrocatalytical reaction, $\mathrm{M}$ is sometimes referred to as electrocatalyst.

$$
\begin{aligned}
& \mathrm{M} \text { (mediator) }-\mathrm{e} \rightarrow \mathrm{M}^{+} \\
& \mathrm{M}_{+}+\mathrm{Tyr} \rightarrow \mathrm{M}+\mathrm{Tyr}^{+}
\end{aligned}
$$

As depicted in Scheme $2 \mathrm{C}$, using Os(bpy $)_{2}(\mathrm{dppz})^{2+}$ as the mediator, the oxidation current of Tyr is 7 -fold greater than that without the mediator. And the second-order rate constant of the redox reaction between Tyr and $\mathrm{Os}\left[(\mathrm{bpy})_{2} \mathrm{dppz}\right]^{2+}$ is calculated to be $2.0( \pm 0.3) \times 10^{3} / \mathrm{M} / \mathrm{s}$ [52]. Thorp and Meyer found that the increase of such catalyzed current is proportional to the concentration of phosphate buffer, from which two mechanisms were proposed: electron and proton transfer (EPT) or proton transfer followed by electron transfer (PT-ET) [49,50]. As depicted in Scheme 2D, the formation of $\operatorname{ArOH}-\mathrm{OP}(\mathrm{OH})-$ $\mathrm{O}_{2}{ }^{2-}$ initiates two different pathways: electrons and protons were retained jointly (EPT, left) or progressively (PTET, right), indicating the possibility of multi-site electroproton transfer [102]. We need to point out that catalyzed current signal was also observed using Trp [52], but Trp makes much less contribution in protein analysis because its reaction rate is relatively low and there is much less Trp than Tyr [e.g., 20 Tyr and 3 Trp in bovine serum albumin (BSA)]. Marginal catalyzed current signal was observed in the presence of other AA residues due to their unmatched energy levels (oxidation potentials) compared with that of Os complexes.

\section{Label-free protein biosensors based on tyrosine electrocatalytic oxidation}

The achievement of signal enhancement allows the detection of protein-conformation changes [52], proteinligand interaction [89], oxidative damage to protein [90], and protein phosphorylation [92]. The detection principles are illustrated conceptually in Scheme 3. In comparison with the intact protein, Tyr residues located in the interior of the protein become more accessible to the redox mediator when the protein unfolds, resulting in higher EC current (Scheme 3 II and III). By contrast, binding of a ligand to a protein blocks the diffusion pathway of the redox mediator toward Tyr if the AA residue resides in the binding pocket. This would reduce the current signal (Scheme 3 IV). Although Tyr can be oxidized by Os(bpy $)_{2} \mathrm{~L}^{3+}$, phosphorylated Tyr and oxidized Tyr cannot, so, if Tyr is phosphorylated under the action of protein tyrosine kinase (PTK), or oxidized by strong chemical oxidizers, the catalyzed current will be lost (Scheme $3 \mathrm{~V}$ and VI). These principles were proved in the recent work done by our group [52,90,91] and others $[58,59,103]$.

\subsection{Monitoring protein-conformation change}

From chemical point of view, a protein is made from a long chain of AAs, each of which is linked to its neighbor via a covalent peptide bond. The three-dimensional conformation of a protein is determined by the sequence of AAs and stabilized by three types of weak forces (hydrogen bonds, ionic bonds, and van der Waals forces) and hydrophobic effect [1]. Local hydrogen bonds lead to two common folding patterns, $\alpha$ helix and $\beta$ sheet. And the hydrophobic side chains (e.g., Phe, Leu, Val, Tyr and Trp residues) are prone to clustering in the interior of a protein molecule. Such specific folding aims to maintain the lowest energy.

Slightly physical or chemical changes in the environment of a protein may break the balance of these forces, leading to conformation alteration. Such changes do not disrupt the sequence of AAs (the primary structure of protein), but unfold a protein into a randomly coiled and disordered structure. Such protein denaturation is commonly induced by exposure to excessive chemicals or by heating \{e.g., urea can directly accumulate onto several AAs and disturb both electrostatic and van der Waals forces ([104] and references therein), thereby destabilizing the folded structure of the protein (Fig. 2, right)\}. Hydrophobic pockets (cavities) inside the protein would be destroyed, and the AA residues buried in the cavities become more accessible to the solvent. It therefore offers an opportunity for us to monitor protein-conformation change by detecting the EC signal from those AAs (or cofactors), which we expect to increase after protein denaturation.

Compared with conventional techniques \{e.g., MS, fluorescence, calorimetry, circular dichroism, IR/Raman spectroscopy, NMR, and computer modeling [104106]\}, electrochemistry is a simple but informative technique to probe protein-conformation change (folding/unfolding). Previously, the denaturation (and catalytic activity) of proteins with redox co-factors have been investigated extensively \{e.g., glucose oxidase (GOx) [107], cytochrome (Cyt) c: [108-111], hemoglobin (Hb) $[112,113]\}$. As shown in Table 3, CNTs [107], nanotextured diamond [114], nanoclay [115,116], and AuNPs [117] were successful in enhancing the direct EC signal from co-factors.

However, the majority of proteins do not contain any redox co-factors. Consequently, EC investigation of these co-factor-free proteins has been rare. Our group employed the electrocatalytic oxidation current of Tyr as the detection signal for monitoring urea-induced unfolding of a co-factor-free protein, BSA [52]. As shown in the cyclic voltammograms in Fig. 2, the electrooxidation current of native BSA catalyzed by Os (bpy) ${ }_{2} \mathrm{dppz}^{2+}$ was 7 -fold higher than BSA alone, which resembles the case of free Tyr. However, the second order rate constant between $\mathrm{BSA}$ and $\mathrm{Os}(\mathrm{bpy})_{2} \mathrm{dppz}^{2+}$ was 


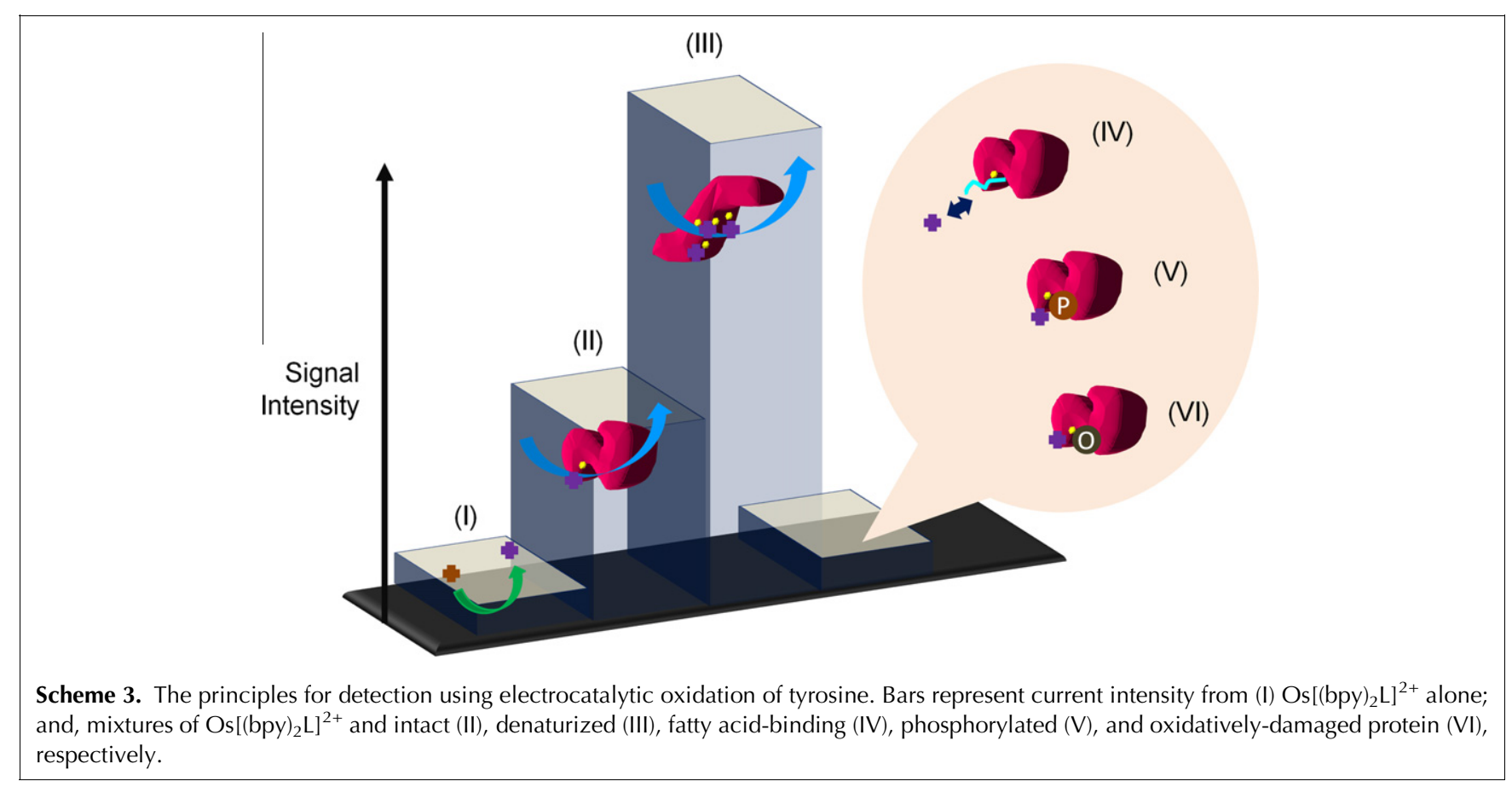

found to be only $12.0 / \mathrm{M} / \mathrm{s}$, which is about 200 -fold slower than that with free $\operatorname{Tyr}\left(2.0 \times 10^{3} / \mathrm{M} / \mathrm{s}\right)$. Also, the current from BSA $(\sim 3.1 \mu \mathrm{A})$ was apparently smaller than that of the latter $(\sim 5.5 \mu \mathrm{A})$ despite having nearly same number of Tyr in both cases. This indicates that the folded structure of BSA is relatively compact and diffusion of the mediator inside the protein is retarded. The contact of the mediator with Tyr residues of BSA is

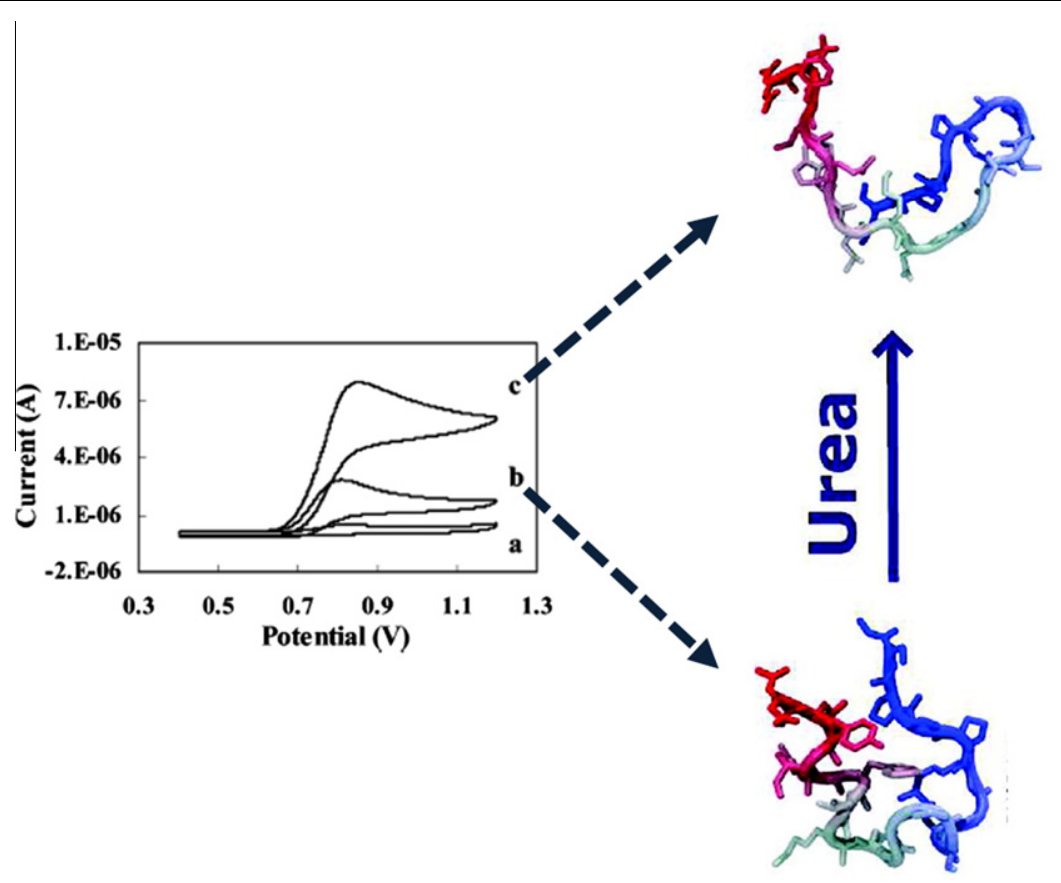

Figure 2. Monitoring protein-conformation change based on electrocatalytic oxidation of tyrosine. Left: cyclic voltammograms of (a) bovine serum albumin (BSA), (b) after addition of Os(bpy $)_{2} \mathrm{dppz}$, and (c) after addition of Os(bpy) ${ }_{2} \mathrm{dppz}$ and urea (Reprinted with permission from [52], ( 2006 , American Chemical Society). Right: denaturation of BSA induced by urea (Reprinted with permission from [104], ( 2010, American Chemical Society). 
therefore not as frequent as with free Tyr. Upon addition of urea, the catalyzed current of BSA increased by 3 times (Fig. 2-c), along with an increased rate constant of $106.0 / \mathrm{M} / \mathrm{s}$. This is probably attributable to the wideopened backbone of BSA after denaturation (Fig. 2, top right), giving rise to better permeability of the redox mediator. The catalyzed current of unfolded BSA was found to depend on the urea concentration, and the dependence was consistent with fluorescence measurement [105], which validated the EC method.

Taking advantage of the unique properties of BDD electrodes, Einaga and co-workers monitored the conformation change of BSA by comparing its oxidation peak at a high potential of $1300 \mathrm{mV}$ before and after addition of urea [67]. At least five redox-active species are involved in the oxidation reaction: Tyr, Tpr, Cys, Met, and disulfide bonds. The oxidation current was found to increase 2 -fold after denaturation. Such an increase was also reported by Kizek and co-worker using SWV on a carbon-paste electrode, referring to the oxidation of Tyr and Trp [54]. In addition, protein-conformation change was investigated by recording signal from disulfide-bond oxidation [118] and electro-active probe [119].

\subsection{Investigation of protein-ligand interaction}

The binding interaction of small molecules with proteins (e.g., nuclear receptors, transport proteins and enzymes) is a very important step for their in vivo functions. For example, hormones modulate gene expression through the mediation of intracellular hormone receptors, which act as transcription factors. The hormone first binds with the receptor and induces its conformational change. The latter subsequently interacts with the corresponding element on DNA and initiates gene expression. Hormone-like exogenous chemicals disrupt hormone functions by binding at the same site of the receptor. Extensive studies have therefore been carried out to elucidate the binding properties of chemical ligands with proteins, and the correlation between binding properties and biological functions. High-resolution structural information can be obtained (e.g., with X-ray diffraction crystallography and NMR). As complementary methods, fluorescence [105] and electrochemistry are convenient and cost-effective, making them excellent choices for the rapid screening of ligand-protein interactions.

EC detection of protein-ligand interactions was achieved by measuring redox-labeled ligands by means of competitive displacement format or "sequestration electrochemistry" [26], as listed in Table 4. Alternatively, EC signal was generated directly from the cofactors or AAs of proteins [120-123]. Some ligands under investigation are themselves redox active, and can be used as signal generators [124]. EC impedance spectroscopy (EIS) $[125,126]$ or potentiometric membrane technique [127] was employed to monitor the interac- tion of protein-ligand in a label-free way as well. Interestingly, Benson et al. engineered a redox-active cofactor into the maltose-binding protein, which lifted up the co-factor by changing its conformation upon binding with a ligand. EC signal decreased due to the elongated ET distance from the co-factor to the electrode surface $[128,129]$.

Our group investigated the binding interaction between fatty acids (FAs) and human serum albumin (HSA) [89] utilizing the electrocatalytic oxidation of Tyr as EC signal, as depicted in Schemes 2 and 3 (IV). HSA is a very important transport protein in plasma, and it binds with a large variety of endogenous ligands and exogenous chemicals [130-134]. Binding these small molecules with HSA has a significant impact on their in vivo distribution, metabolism, and bio-availability. Structural studies have shown that there are 7 binding sites on HSA for fatty acids (FAs), and, in the complex, the hydrophobic tails of FAs insert into the hydrophobic cavities of HSA [130,134], as shown in Fig. 3A. The protein has 20 Tyr residues, and many of them are located in those cavities (marked as yellow halos, Fig. 1B), suggesting the possibility of investigating FA-HSA binding interactions with our Tyr-based signal-enhancing system.

In our study, the catalyzed oxidation current of native HSA was found to decrease significantly after addition of octanoic acid (Fig. 3B), and the degree of signal reduction depended on its concentration. However, for the HSA denatured by urea, addition of octanoic acid did not bring any change to the protein's EC signal [89]. One can hypothesize that, binding of octanoic acid with HSA fills up the cavities where many of the Tyr residues reside, and thus impedes the diffusion of the redox mediator to these residues. This reduces EC current. However, for the chemically denatured protein, there is no ligand binding, and therefore no change of EC signal. Our study suggests that the Tyr-based signal-enhancing EC system can be used as a screening tool for the rapid assessment of ligand-protein interactions.

\subsection{Detection of oxidative damage to proteins}

It has been recognized for many years that oxidative damage to proteins is involved in a number of pathologies, including cancers and aging processes [135]. The imbalance among pro-oxidants, antioxidants and proteolytic activities may lead to the generation of excessive reactive oxygen species (ROS) (Fig. 4A). Many AA residues can be oxidized by ROS [136], including Met, Cys, Trp, Tyr, His, Pro, Arg, and Lys by the hydroxylation of aromatic groups and aliphatic AA side chains, or the conversion of some AA residues to carbonyl derivatives. Most of these AA modifications can be used as useful markers for total protein oxidation. The most common methods to identify oxidized proteins rely on analytical chemistry instruments \{e.g., GC or HPLC coupled with MS) [136,137]. More recently, fluorescence-based 
Table 3. Summary of the three strategies of signal enhancement for the detection of protein-conformation change

\begin{tabular}{|c|c|c|c|c|c|c|}
\hline \multicolumn{2}{|c|}{ Strategies for signal enhancement } & \multirow{3}{*}{$\begin{array}{l}\begin{array}{l}\text { Protein } \\
\text { /peptide }\end{array} \\
\text { P53 } \\
\text { hIAPP }\end{array}$} & \multirow{3}{*}{\begin{tabular}{l}
\multicolumn{1}{c}{$\begin{array}{c}\text { Signal } \\
\text { generator }\end{array}$} \\
Tyr, Trp \\
Tyr
\end{tabular}} & \multirow{3}{*}{$\begin{array}{l}\begin{array}{l}\text { Denaturant } \\
\text { /aggregation }\end{array} \\
\begin{array}{l}\text { Urea } \\
\text { Aggregation }\end{array}\end{array}$} & \multirow{3}{*}{$\begin{array}{l}\begin{array}{c}\text { Solution/ } \\
\text { surface }\end{array} \\
\text { In solution } \\
\text { On surface }\end{array}$} & \multirow{2}{*}{$\begin{array}{l}\text { Ref. } \\
{[54]}\end{array}$} \\
\hline Background & SWV & & & & & \\
\hline subtraction & & & & & & [55] \\
\hline & BDD & BSA & $\begin{array}{l}\text { Try, Trp, Cys, Met, } \\
\text { S-S bond }\end{array}$ & Urea & In solution & [67] \\
\hline \multirow{4}{*}{$\begin{array}{l}\text { Electrode surface modification } \\
\text { (nanomaterials) }\end{array}$} & CNTs & GOx & FAD & Heat & On surface & [107] \\
\hline & Diamond textures & Cyt C & Heme & Cardiolipin & In solution & [114] \\
\hline & Clay & $\mathrm{Hb}$ & Heme & Urea & On surface & {$[115,116]$} \\
\hline & Gold NPs & $\mathrm{Hb}$ & Heme & Gold NPs & On surface & {$[117]$} \\
\hline $\begin{array}{l}\text { Electrocatalysis } \\
\text { with redox } \\
\text { mediators }\end{array}$ & Tyr \& Os complex & BSA & Tyr & Urea & In solution & [52] \\
\hline
\end{tabular}

approaches for the detection of oxidative stress with high sensitivity have emerged $[138,139]$.

Tyr-oxidation products (e.g., dityrosine or Dopa) have been used as indicators of oxidative stress because Tyr is present in significant quantities in vivo, and readily reacts with electrophilic free radicals to form stable derivatives. The EC response of Tyr-oxidation products may differ substantially from Tyr itself, thus providing an opportunity for us to develop EC sensors for the detection of protein oxidation. Using Tyr-based label-free EC protein biosensor, our group pioneered the detection of protein oxidative damage induced by ROS [90]. One inevitable issue in the development of a protein biosensor is protein immobilization, which is mainly achieved by three strategies: physical adsorption, covalent reaction and bio-affinity immobilization ([140] and references therein).
In our work, a layer-by-layer self-assembly technique was employed to fabricate the sensor. Poly(diallyldimethylammonium chloride) (PDDA), a positively-charged polymer, was first immobilized on an ITO electrode by electrostatic attraction, followed by adsorption of a negatively-charged polypeptide, poly(glu, tyr, 4:1) (Fig. 4B). As in solution, the Tyr-containing peptide immobilized on the electrode produced a significant amount of EC current catalyzed by Os(bpy $)_{3}{ }^{2+}$. However, after the sensor was incubated with a solution mixture of $\mathrm{Fe}^{2+} / \mathrm{H}_{2} \mathrm{O}_{2}$, which is known to generate hydroxyl radicals, the EC current dropped substantially. More detailed investigation allowed us to postulate that, upon exposure to the Fenton reagents, Tyr in the polypeptide was oxidized to L-dopa, which subsequently formed a chelating complex with $\mathrm{Fe}$ (III). The formation of the complex, not surprisingly, suppressed the electrocatalytic
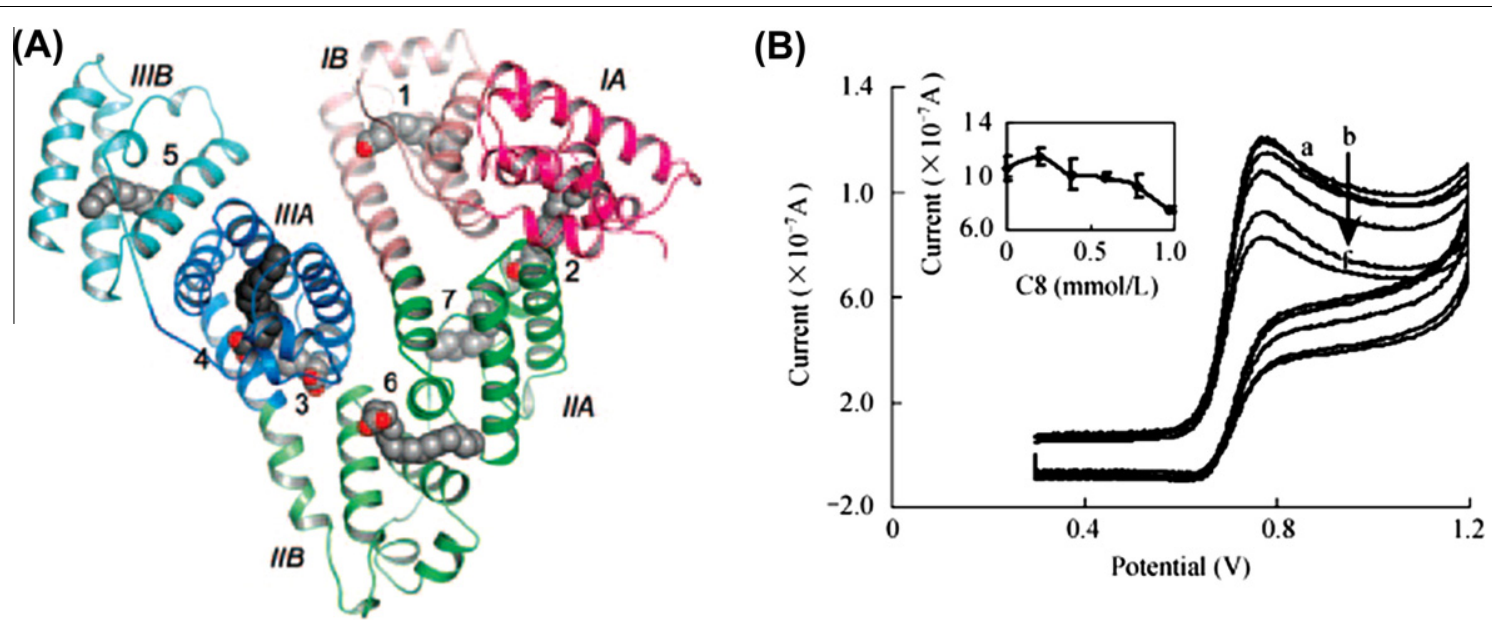

Figure 3. (A) Crystal structure of human serum albumin (HSA) with 7 binding sites of fatty acid, as revealed by X-ray crystallography. Three domains were marked in red, green, and blue, along with A and B sub-domains (dark- and light-colored shades, respectively) (Reprinted with permission from [134], ( 2005 , National Academy of Science). (B) Cyclic voltammograms of HSA in the presence of Os(bpy) ${ }_{3}{ }^{2+}$ with addition of C8. Arrow indicates the increasing of C8 concentration. Inset: catalyzed oxidation current as a function of C8 concentrations (Reprinted with permission from [89], (2009, The Research Centre for Eco-Environmental Sciences, Chinese Academy of Sciences). 


\begin{tabular}{|c|c|c|c|c|c|c|}
\hline \multicolumn{3}{|c|}{ Detection strategies } & Protein & Ligand & $\begin{array}{l}\text { Solution } \\
\text { /surface }\end{array}$ & Ref. \\
\hline \multirow[t]{7}{*}{ Label-based } & labels & PoPD & BSA & papaverine & On surface & [20] \\
\hline & & Iron (II) complex & Avidin & Biotin & In solution & {$[21]$} \\
\hline & & Nile blue & Avidin & Biotin & In solution & {$[22]$} \\
\hline & & daunomycin & Avidin & biotin & On surface & [23] \\
\hline & & CdS QDs & ER-LBD & peptide & On surface & {$[24]$} \\
\hline & & Ferrocene & HSA & Fatty acid & In solution & {$[25]$} \\
\hline & & daunomycin & Cholera toxin & lactose & $\begin{array}{l}\text { In solution } \\
(\text { CNTP) }\end{array}$ & {$[26]$} \\
\hline \multirow[t]{11}{*}{ Label-free } & Intrinsic signal & Heme & Myoglobin & Imidazole & On surface & {$[120]$} \\
\hline & From protein & & S824C & exogenous $\mathrm{N}$-donor ligands & On surface & {$[121]$} \\
\hline & & & $\begin{array}{l}\text { Hemoglobin } \\
\text { (Ag NPs) }\end{array}$ & GTP & In solution & {$[122]$} \\
\hline & & FAD & $\begin{array}{l}\text { XOD } \\
\left(\mathrm{TiO}_{2} \mathrm{NPs}\right)\end{array}$ & Nitric oxide & On surface & [123] \\
\hline & & Tyrosine (Electrocatalysis) & HSA & Fatty acids & In solution & [89] \\
\hline & Intrinsic signal & Rhodamine B & BSA & Rhodamine B & In solution & {$[173]$} \\
\hline & From ligand & $\begin{array}{l}\text { ANS \& } \\
\mathrm{Cu}^{2+} / \mathrm{Ag}^{+}\end{array}$ & HSA & ANS \& $\mathrm{Cu}^{2+} / \mathrm{Ag}^{+}$ & On surface & [124] \\
\hline & & Cup-Cd (II) & HSA & Cup-Cd (II) & In solution & {$[174]$} \\
\hline & EC methods & $\mathrm{E}(\mathrm{Q}) \mathrm{IS}$ & BSA & Tannin & On surface & {$[125]$} \\
\hline & & & antithrombin & Heparin & On surface & {$[126]$} \\
\hline & & $\begin{array}{l}\text { Potentiometric } \\
\text { membrane }\end{array}$ & HSA & $\mathrm{Er}^{3+}$ & In solution & {$[127]$} \\
\hline \multirow[t]{4}{*}{ Other } & & Clamp-like protein biosensors & (MBP) & & On surface & {$[128,129]$} \\
\hline & & & GBP & Glucose & & \\
\hline & & & ZBP & Zinc ion & & \\
\hline & & & QBP & glutamine & & \\
\hline
\end{tabular}

oxidation of Tyr and L-dopa. Suppression of EC signal depended on the concentration of Fenton reagent and the incubation time. Loss of EC current was observed within 3 min after exposure to $\mathrm{Fe}^{2+} / \mathrm{H}_{2} \mathrm{O}_{2}$, indicating fast kinetics of the damage reaction (Fig. 4C). In addition, the lowest concentration at which the peptide damage was detected was $10 \mu \mathrm{M} \mathrm{Fe}^{2+}$ and $\mathrm{H}_{2} \mathrm{O}_{2}$. This concentration is close to the $\mathrm{Fe}^{2+}$ and $\mathrm{H}_{2} \mathrm{O}_{2}$ levels found in vivo, suggesting that the $\mathrm{EC}$ sensor can detect protein damage induced by chemicals at physiologically relevant concentrations.

A biosensor was also developed for the detection of oxidative damage to BSA, using poly-o-phenylenediamine as an electro-active probe [141], in which damaged BSA appeared to hinder the charge transfer of the probe on the electrode surface.

\subsection{Detection of protein phosphorylation and kinase activity}

Protein phosphorylation is a process in which a phosphoryl group is transferred from the position of ATP to the hydroxyl group of a protein or polypeptide AA under the catalytic action of a class of enzymes called protein kinases. Phosphorylation usually occurs on serine (Ser), threonine (Thr) or Tyr residues of proteins. Protein phosphorylation is considered the most important PTM process, since it regulates a wide range of biological processes, including cellular proliferation, differentiation, development and apoptosis, signal transduction, nervous activity, muscle contraction, metabolism and oncogenesis [9]. As such, protein kinases have emerged as promising targets for cancer therapy, and small-molecule inhibitors of kinases have attracted enormous research interest in the development of anticancer drugs. A number of enzyme assays and enzyme sensors have been developed for the detection of protein phosphorylation and protein-kinase inhibition [142-147]. Among them, EC protein biosensors overshadow the others for screening due to their inherent advantages of speed, convenience and cost effectiveness. As shown in Table 5, EC detection of protein phosphorylation falls into two general categories: redox-labeled ATP conjugates; and, label-free detection.

It is relatively straightforward to attach a redox-active group as signal reporter to the terminal phosphate of ATP, which is then transferred to an AA during protein phosphorylation. Consequently, the signal intensity goes up along with the phosphorylation process. Such "Signal 

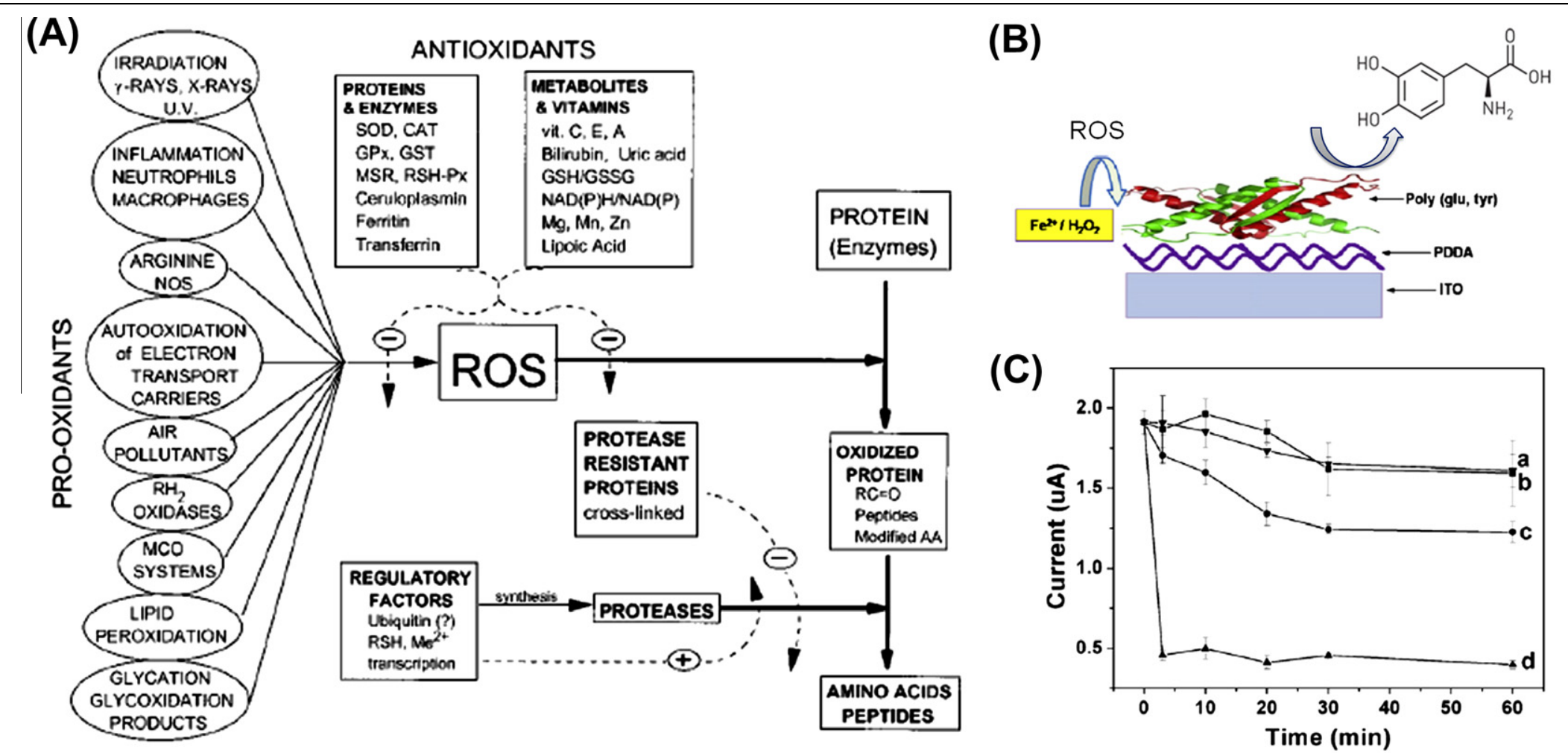

Figure 4. (A) ROS-induced protein oxidative damage (Adapted from [135] with permission, @1997, American Society for Biochemistry and Molecular Biology). (B Assembly of polypeptide biosensor for the detection of ROS-induced oxidative damage. Chemical structure of the oxidation product of tyrosine, L-dopa, is given. (C) Plot for the dependence of electro-catalyzed oxidation current as function of incubation time. Measurements were carried out after incubation with (a) $\mathrm{H}_{2} \mathrm{O}$, (b) $\mathrm{H}_{2} \mathrm{O}_{2}$, (c) $\mathrm{FeSO}_{4}$, and (d) $\mathrm{H}_{2} \mathrm{O}_{2} / \mathrm{FeSO}_{4}$. (Reprinted with permission from [90], @2011, Elsevier BV). 


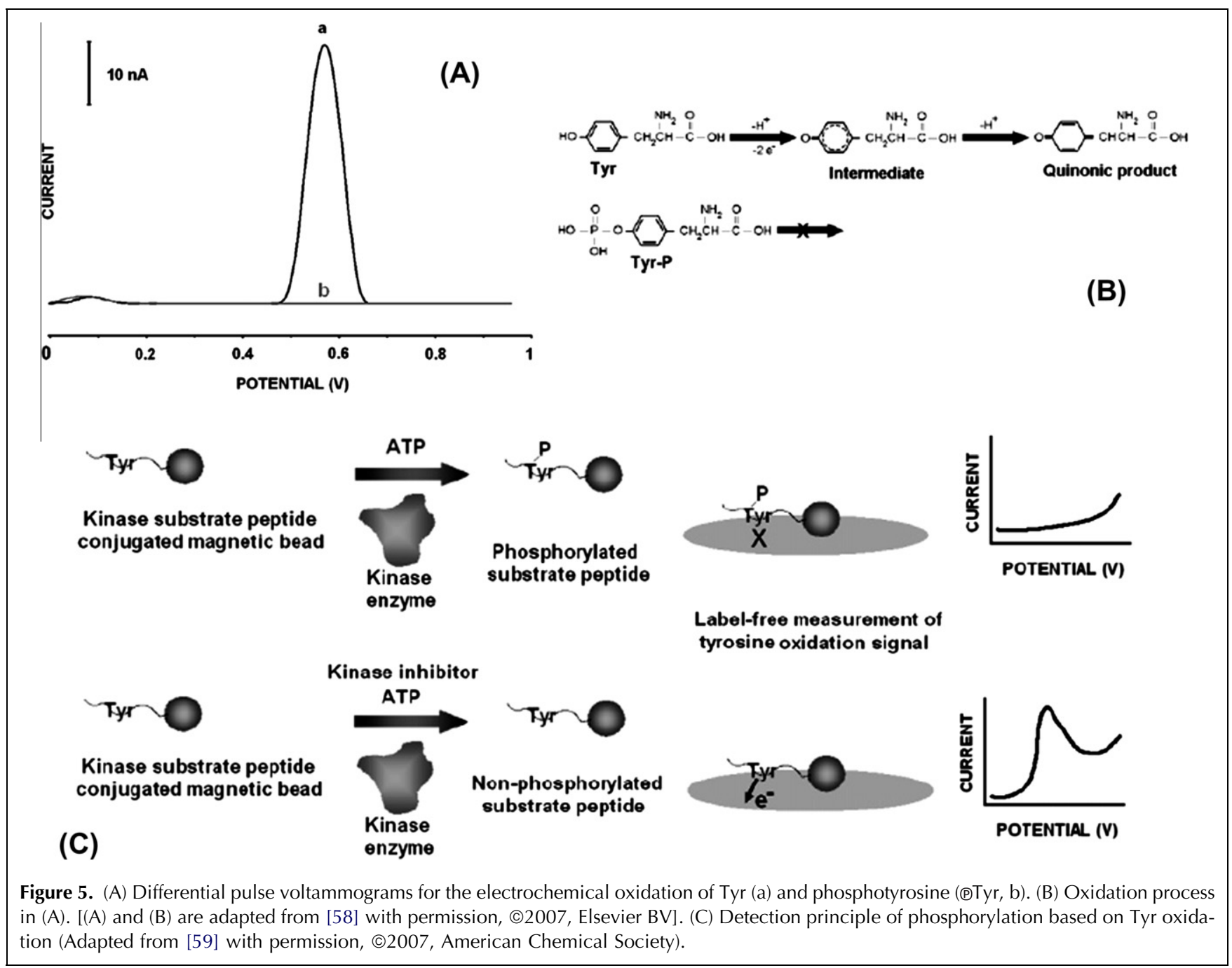

by reaction between the amine group of the peptide and the epoxy functionality of GPTMS (Fig. 6B). Since the amino group is at the terminal, the peptide should be in a perpendicular orientation and favorable for kinase recognition.

Another challenge was to maintain the EC activity of the redox mediator. Although $\mathrm{Os}(\mathrm{bpy})_{3}{ }^{2+}$ is electrochemically active on bare ITO electrodes, immobilization of GPTMS may retard its reaction due to the non-conductive nature of the organic molecules [159]. Therefore, although high surface density of GPTMS is beneficial to peptide immobilization, it is not productive to EC-signal generation (Fig. 7). To identify the optimum surface modification, the EC response of Os(bpy $)_{3}{ }^{2+}$ was investigated on ITO electrodes modified with GPTMS for different reaction times. It was found that the EC current of Os(bpy) ${ }_{3}{ }^{2+}$ did not change until the modification exceeded $1 \mathrm{~h}$. Under these conditions, the catalyzed oxidation current of poly(glu, tyr) immobilized on ITO was $\sim 30$ times larger than without Os(bpy $)_{3}{ }^{2+}$ media- tion, demonstrating the high electro-activity of the mediator (Fig. 7).

Epidermal growth factor receptor (EGFR) was chosen as target kinase for our study due to its heavy involvement in the formation of tumors by phosphorylationregulated signaling pathways (Fig. 6A) [160]. A better understanding of the activity and the inhibition of this enzyme could shed light on the development of anticancer drugs [161]. Addition of EGFR and ATP to the above system resulted in a marked reduction in EC signal, indicating successful conversion of native Tyr to phosphotyrosine. However, signal reduction was prohibited when an EGFR inhibitor was also present. The degree of EC-signal recovery depended on the concentration of the inhibitor, and a plot of EC current against inhibitor concentration yielded a typical inhibition curve. From the plot, $\mathrm{IC}_{50}$ values and inhibition constants of three known EGFR inhibitors were calculated, and were found to be very close to the numbers reported in the literature. Thus, the new sensor is as effective as 


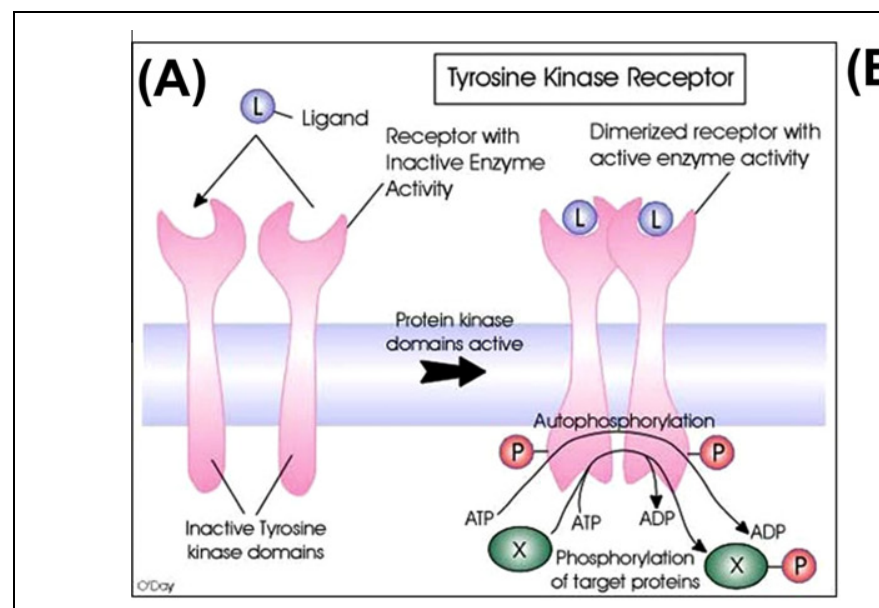

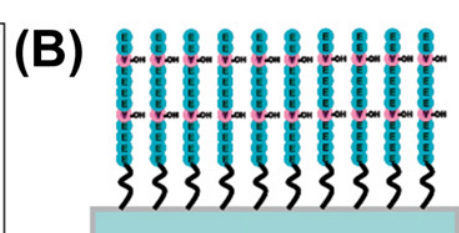

- Glu

- P

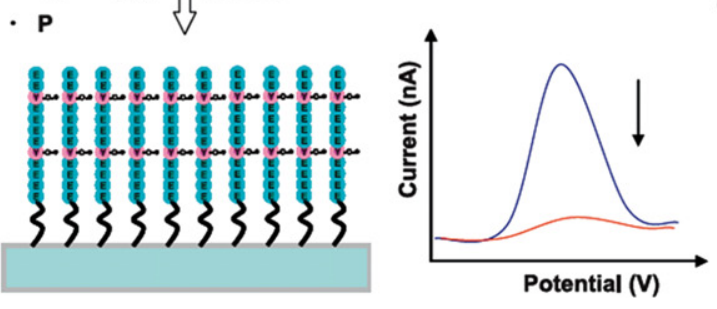

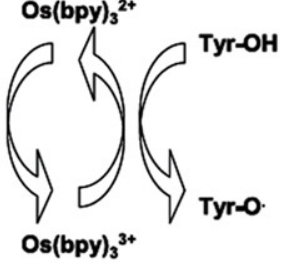

(C)

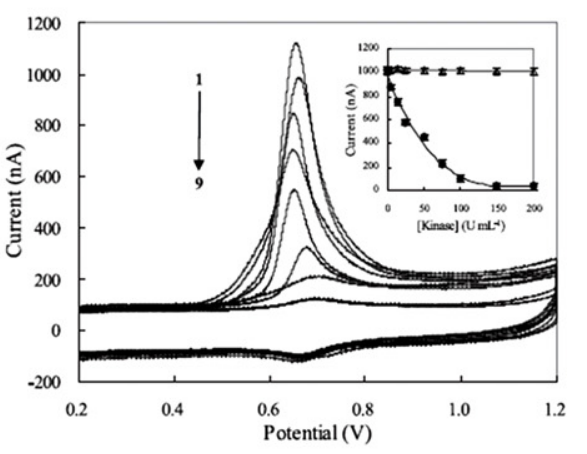

Figure 6. (A) The functions of tyrosine kinase receptor (Adapted from Danton H. O’Day's website with permission (http://anakin.utm.utoronto.ca/ w3oday/). (B) Electrochemical sensing strategy for protein tyrosine kinase (PTK) activity detection using electro-catalyzed Tyr oxidation as signal probe. (C) Cyclic voltammograms of polypeptide-modified electrode in the presence of kinase at varying concentrations. The arrow indicates the increasing concentration of kinase. Inset: Electro-catalyzed oxidation current as function of epidermal growth factor receptor (EGFR) concentration (black circles) or protein kinase A (PKA) (blank triangles) (Adapted from [92] with permission, @2011, Elsevier BV). 


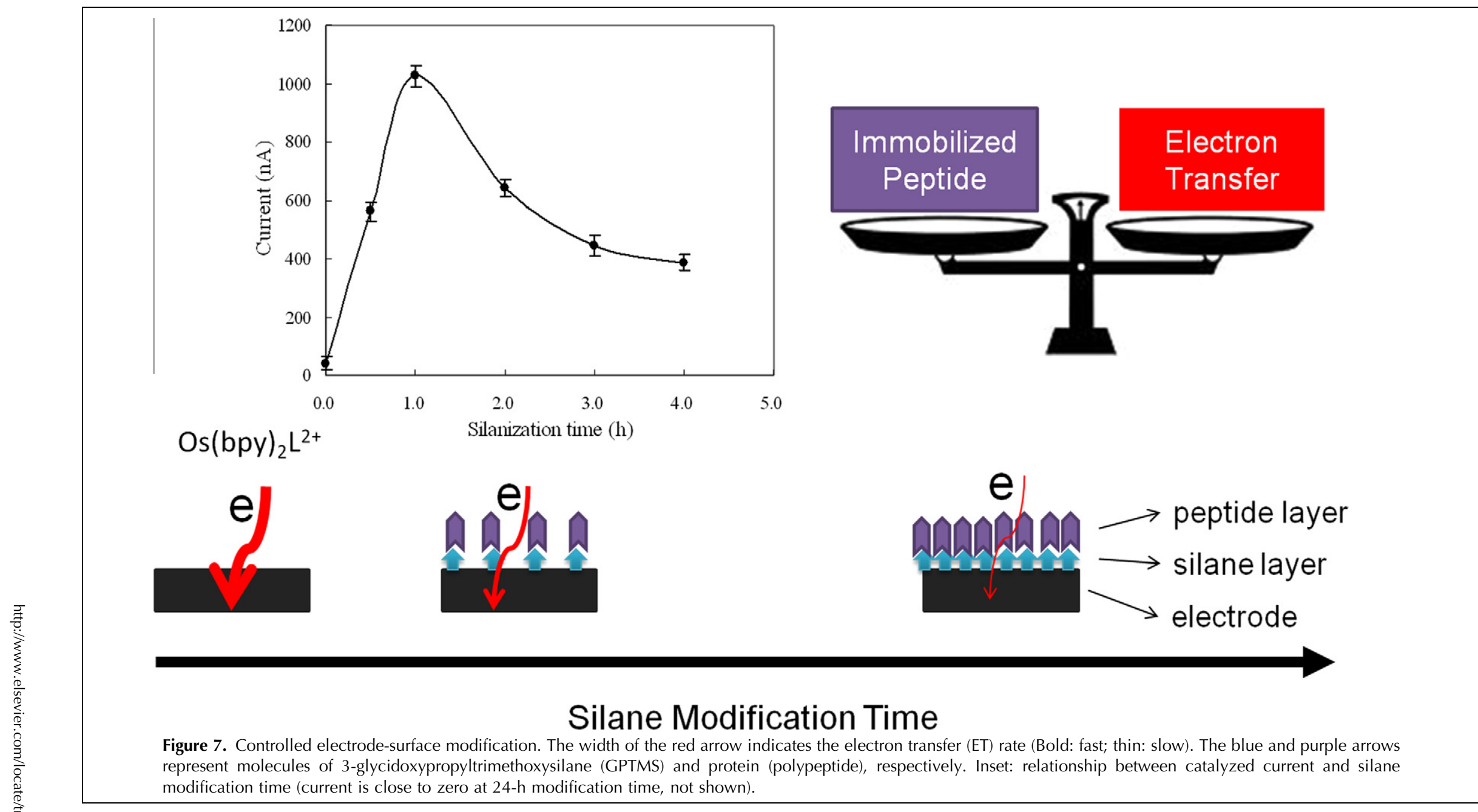


other methods, but is simpler to use and more economical.

\section{Summary and perspectives}

Results in our work and other works suggest that labelfree EC protein biosensor is a rapid, cost-effective, convenient, yet informative tool for protein-function analysis. Electroactivity of some AAs allows for label-free detection in an EC-protein biosensor, whereby valid information about protein functions can be obtained without disrupting protein structures. However, EC signal is limited due to the irreversible EC reaction of these AAs on most common electrodes and the sluggish ET kinetics that originates from the location of these AAs in the interior of proteins. Consequently, signal enhancement becomes crucial.

Our group developed a signal-enhancing system using ITO as the working electrode and Os complex as the redox mediator to oxidize Tyr electro-catalytically [52,89-92]. With this signal-enhancing system, we have demonstrated several applications in proteinfunction analysis, including the detection of protein-conformation change, the investigation of protein-ligand interaction, the detection of oxidative protein damage, and the detection of protein phosphorylation and protein-kinase inhibition.

Real sample detection has rarely been reported for such protein-function analysis, although there were some cases of quantitative analysis of protein in real samples \{e.g., blood $[162,163]\}$. The matrix interference from other electro-active (bio)molecules is a major concern in real sample detection.

The principle of the signal-enhancing system is transformative and goes beyond the results above. One of the prominent advantages of our system is that the redox potential of Os complexes can be fine-tuned by varying ligands $[100,101]$. This indicates a great potential to open the electrocatalytic oxidation to other AAs (e.g., Trp), if necessary. Proof-of-concept work in the application of our system is paving the way for a variety of bio-analytical detections and protein-function analysis in future work [e.g., detection of protein dephosphorylation with phosphatase, and fabrication of a protein-biosensor array (biochip) for screening of kinase inhibitors and toxicity of environmental contaminants].

\section{Acknowledgements}

Financial support for this work was provided by the National Natural Science Foundation of China (20825519, 20890112, and 20921063). This work was also financially supported by a US National Science Foundation grant (NSF-0901303) and a West Virginia EPSCoR Research Challenge Grant.

\section{References}

[1] B. Alberts, Molecular biology of the cell, Garland Science, New York, USA, 2002.

[2] E. Carafoli, J. Biol. Chem. 267 (1992) 2115.

[3] J. Schlessinger, Cell 103 (2000) 211.

[4] W. Kolch, A. Pitt, Nat. Rev. Cancer 10 (2010) 618.

[5] F. Shen, K.Z. Kirmani, Z.M. Xiao, B.H. Thirlby, R.J. Hickey, L.H. Malkas, J. Cell Biochem. 112 (2011) 756.

[6] D.J. Leeming, A.C. Bay-Jensen, E. Vassiliadis, M.R. Larsen, K. Henriksen, M.A. Karsdal, Biomarkers 16 (2011) 193.

[7] R.A. Sowell, J.B. Owen, D.A. Butterfield, Ageing Res. Rev. 8 (2009) 1.

[8] D.P. Hanger, B.H. Anderton, W. Noble, Trends Mol. Med. 15 (2009) 112.

[9] N. Ahn, Chem. Rev. 101 (2001) 2207.

[10] J. Howard, Nature (London) 391 (1998) 239.

[11] A. Huxley, Nature (London) 391 (1998) 239.

[12] W.P. Blackstock, M.P. Weir, Trends Biotechnol. 17 (1999) 121.

[13] IUPAC, Biosens. Bioelectron. 11 (1996) R1.

[14] J. Bermudez-Crespo, J.L. Lopez, Proteom. Clin. Appl. 1 (2007) 983.

[15] C.I.L. Justino, T.A. Rocha-Santos, A.C. Duarte, Trends Anal Chem. 29 (2010) 1172.

[16] H.M. Haake, A. Schutz, G. Gauglitz, Fresenius' J. Anal. Chem. 366 (2000) 576.

[17] M. Vestergaard, K. Kerman, E. Tamiya, Sensors (Basel) 7 (2007) 3442 .

[18] C.K. O’Sullivan, G.G. Guilbault, Biosens. Bioelectron. 14 (1999) 663.

[19] J. Wang, Chem. Rev. 108 (2008) 814.

[20] L.J. Feng, X.H. Zhang, D.M. Zhao, S.F. Wang, Sens, Actuators, B 152 (2011) 88.

[21] K.D. Barker, A.L. Eckermann, M.H. Sazinsky, M.R. Hartings, C. Abajian, D. Georganopoulou, M.A. Ratner, A.C. Rosenzweig, T.J. Meade, Bioconjugate Chem. 20 (2009) 1930.

[22] H. Kuramitz, A. Piruska, H.B. Halsall, C.J. Seliskar, W.R. Heineman, Anal. Chem. 80 (2008) 9642.

[23] K. Sugawara, G. Hirabayashi, N. Kamiya, H. Kuramitz, S. Tanaka, Electroanalysis (NY) 17 (2005) 1659.

[24] J.A. Hansen, V.V. Surnbayev, K.V. Gothelf, Nano Lett. 7 (2007) 2831.

[25] I. Tranchant, A.C. Herve, S. Carlisle, P. Lowe, C.J. Slevin, C. Forssten, J. Dilleen, A.B. Tabor, D.E. Williams, H.C. Hailes, Bioconjugate Chem. 18 (2007) 199.

[26] H. Kuramitz, S. Miyagaki, E. Ueno, N. Hata, S. Taguchi, K. Sugawara, Analyst (Cambridge UK) 136 (2011) 2373.

[27] L.Y. Fang, Z.Z. Lu, H. Wei, E.K. Wang, Biosens. Bioelectron. 23 (2008) 1645.

[28] L.H. Guo, X.Q. Yang, Analyst (Cambridge UK) 130 (2005) 1027.

[29] C.A. Leng, G.S. Lai, F. Yan, H.X. Ju, Anal. Chim. Acta 666 (2010) 97 .

[30] G.S. Lai, F. Yan, J. Wu, C.A. Leng, H.X. Ju, Anal. Chem. 83 (2011) 2726.

[31] W. Siangproh, W. Dungchai, P. Rattanarat, O. Chailapakul, Anal. Chim. Acta 690 (2011) 10.

[32] G. Herzog, D.W.M. Arrigan, Analyst (Cambridge, UK) 132 (2007) 615.

[33] E. Palecek, V. Ostatna, Electroanalysis (NY) 19 (2007) 2383.

[34] H.Q. Li, A.C. Chen, S.G. Roscoe, J. Lipkowski, J. Electroanal. Chem. 500 (2001) 299.

[35] X.H. Cai, G. Rivas, P.A.M. Farias, H. Shiraishi, J. Wang, E. Palecek, Anal. Chim. Acta 332 (1996) 49.

[36] W.T. Tan, J.K. Goh, Electroanalysis (NY) 20 (2008) 2447.

[37] K. Huvaere, L.H. Skibsted, J. Am. Chem. Soc. 131 (2009) 8049.

[38] J.B. Raoof, R. Ojani, H. Beitollahi, Electroanalysis (NY) 19 (2007) 1822. 
[39] T. Noll, G. Noll, Chem. Soc. Rev. 40 (2011) 3564.

[40] M. Vasjari, A. Merkoci, J.P. Hart, S. Alegret, Microchim. Acta 150 (2005) 233.

[41] A. Babaei, M. Zendehdel, B. Khalilzadeh, A. Taheri, Colloids Surf., B 66 (2008) 226.

[42] N.T. Nguyen, M.Z. Wrona, G. Dryhurst, J. Electroanal. Chem. 199 (1986) 101.

[43] O. Nekrassova, G.D. Allen, N.S. Lawrence, L. Jiang, T.G.J. Jones, R.G. Compton, Electroanalysis (NY) 14 (2002) 1464.

[44] Q.L. Sheng, H. Yu, J.B. Zheng, J. Solid State Electron 12 (2008) 1077.

[45] S.D. Holmstrom, J.A. Cox, Anal. Chem. 72 (2000) 3191.

[46] A. Salimi, R. Hallaj, M.K. Amini, Anal. Chim. Acta 534 (2005) 335.

[47] N.S. Lawrence, J. Davis, R.G. Compton, Talanta 53 (2001) 1089.

[48] O. Nekrassova, J. Kershaw, J.D. Wadhawan, N.S. Lawrence, R.G. Compton, Phys. Chem. Chem. Phys. 6 (2004) 1316.

[49] C.J. Fecenko, T.J. Meyer, H.H. Thorp, J. Am. Chem. Soc. 128 (2006) 11020.

[50] C.J. Fecenko, T.J. Meyer, H.H. Thorp, J. Am. Chem. Soc. 132 (2010) 5323

[51] A.K. Srivastava, R.R. Gaichore, Anal. Lett. 43 (2010) 1933.

[52] L.H. Guo, N. Qu, Anal. Chem. 78 (2006) 6275.

[53] M. Masarik, A. Stobiecka, R. Kizek, F. Jelen, Z. Pechan, W. Hoyer, T.M. Jovin, V. Subramaniam, E. Palecek, Electroanalysis (NY) 16 (2004) 1172.

[54] D. Potesil, R. Mikelova, V. Adam, R. Kizek, R. Prusa, Protein J. 25 (2006) 23.

[55] N. Zhou, Z.Y. Chen, D.M. Zhang, G.X. Li, Sensors (Basel) 8 (2008) 5987.

[56] Q. Xu, S.F. Wang, Microchim. Acta 151 (2005) 47.

[57] J. Geng, H.J. Yu, J.S. Ren, X.G. Qu, Electrochem. Commun. 10 (2008) 1797.

[58] K. Kerman, M. Vestergaard, M. Chikae, S. Yamamura, E. Tamiya, Electrochem. Commun. 9 (2007) 976.

[59] K. Kerman, M. Vestergaard, E. Tamiya, Anal. Chem. 79 (2007) 6881.

[60] S.Y. Huan, G.L. Shen, R.Q. Yu, Electroanalysis (NY) 16 (2004) 1019.

[61] L. Moreno, A. Merkoci, S. Alegret, S. Hernandez-Cassou, J. Saurina, Anal. Chim. Acta 507 (2004) 247.

[62] J. Okuno, K. Maehashi, K. Matsumoto, K. Kerman, Y. Takamura, E. Tamiya, Electrochem. Commun. 9 (2007) 13.

[63] J.H.T. Luong, K.B. Male, J.D. Glennon, Analyst (Cambridge UK) 134 (2009) 1965.

[64] N. Spataru, B.V. Sarada, E. Popa, D.A. Tryk, A. Fujishima, Anal. Chem. 73 (2001) 514

[65] T.A. Ivandini, B.V. Sarada, C. Terashima, T.N. Rao, D.A. Tryk, H. Ishiguro, Y. Kubota, A. Fujishima, J. Chromatogr., B 791 (2003) 63.

[66] D. Shin, D.A. Tryk, A. Fujishima, A. Merkoci, J. Wang, Electroanalysis (NY) 17 (2005) 305.

[67] M. Chiku, J. Nakamura, A. Fujishima, Y. Einaga, Anal. Chem. 80 (2008) 5783

[68] M. Chiku, K. Horisawa, N. Doi, H. Yanagawa, Y. Einaga, Biosens. Bioelectron. 26 (2010) 235.

[69] M.-Y. Wei, R. Huang, L.-H. Guo, J. Electroanal. Chem. 664 (2012) 156

[70] F.H. Wu, G.C. Zhao, X.W. Wei, Z.S. Yang, Microchim. Acta 144 (2004) 243.

[71] Y.J. Guo, S.J. Guo, Y.X. Fang, S.J. Dong, Electrochim. Acta 55 (2010) 3927.

[72] X.Z. Yu, Z.B. Mai, Y. Xiao, X.Y. Zou, Electroanalysis (NY) 20 (2008) 1246.

[73] J.M. Xu, Y.P. Wang, Y.Z. Xian, L.T. Jin, K. Tanaka, Talanta 60 (2003) 1123.
[74] C.Y. Deng, J.H. Chen, X.L. Chen, M.D. Wang, Z. Nie, S.Z. Yao, Electrochim. Acta 54 (2009) 3298.

[75] S.H. Zhang, W.Y. Qu, W.S. Huang, Y.Y. Wu, J. Nanosci. Nanotechnol. 4 (2004) 553.

[76] X.F. Tang, Y. Liu, H.Q. Hou, T.Y. You, Talanta 80 (2010) 2182.

[77] A. Safavi, S. Momeni, Electroanalysis (NY) 22 (2010) 2848.

[78] C.Y. Li, Y. Ya, G.Q. Zhan, Colloids Surf., B 76 (2010) 340.

[79] H. Razmi, H. Heidari, Anal. Biochem. 388 (2009) 15.

[80] S. Shahrokhian, M. Bayat, Microchim. Acta 174 (2011) 361.

[81] Y. Fan, J.H. Liu, H.T. Lu, Q. Zhang, Microchim. Acta 173 (2011) 241.

[82] G.P. Jin, X. Peng, Q.Z. Chen, Electroanalysis (NY) 20 (2008) 907

[83] A. Chou, T. Bocking, N.K. Singh, J.J. Gooding, Chem. Commun. (2005) 842.

[84] C.E. Banks, R.R. Moore, T.J. Davies, R.G. Compton, Chem. Commun. (2004) 1804

[85] C.E. Banks, T.J. Davies, G.G. Wildgoose, R.G. Compton, Chem. Commun. (2005) 829 .

[86] I. Willner, B. Willner, Nano Lett. 10 (2010) 3805.

[87] Y. Xiao, F. Patolsky, E. Katz, J.F. Hainfeld, I. Willner, Science (Washington DC) 299 (2003) 1877.

[88] F. Patolsky, Y. Weizmann, I. Willner, Angew. Chem., Int. Edit. Engl. 43 (2004) 2113.

[89] Y.M. Chen, L.H. Guo, J. Environ. Sci. China 21 (2009) 373.

[90] N. Qu, L.H. Guo, B.Z. Zhu, Biosens. Bioelectron. 26 (2011) 2292.

[91] N. Qu, B. Wan, L.H. Guo, Analyst (Cambridge UK) 133 (2008) 1246.

[92] Y. Yang, L.H. Guo, N. Qu, M.Y. Wei, L.X. Zhao, B. Wan, Biosens. Bioelectron. 28 (2011) 284

[93] P. Yeh, T. Kuwana, Chem. Lett. (1977) 1145.

[94] M.J. Eddowes, H.A.O. Hill, J. Chem. Soc. Chem. Comm. (1977) 771.

[95] V. Brabec, Bioelectrochem. Bioenerg. 7 (1980) 69.

[96] J.A. Reynaud, B. Malfoy, A. Bere, Bioelectrochem. Bioenerg. 7 (1980) 595.

[97] V. Brabec, I. Schindlerova, Bioelectrochem. Bioenerg. 8 (1981) 451.

[98] V. Brabec, V. Mornstein, Biophys. Chem. 12 (1980) 159.

[99] N.C. Reynolds, B.M. Kissela, L.H. Fleming, Electroanalysis (NY) 7 (1995) 1177.

[100] K. Maruyama, Y. Mishima, K. Minagawa, J. Motonaka, Anal. Chem. 74 (2002) 3698

[101] C.R. Arana, H.D. Abruna, Inorg. Chem. 32 (1993) 194.

[102] M.H.V. Huynh, T.J. Meyer, Chem. Rev. 107 (2007) 5004.

[103] H.F. Song, K. Kerman, H.B. Kraatz, Chem. Commun. (2008) 502.

[104] D.R. Canchi, D. Paschek, A.E. Garcia, J. Am. Chem. Soc. 132 (2010) 2338.

[105] C.A. Royer, Chem. Rev. 106 (2006) 1769.

[106] P.G. Righetti, B. Verzola, Electrophoresis 22 (2001) 2359.

[107] Q.A. Wang, W. Xu, P. Wu, H. Zhang, C.X. Cai, B. Zhao, J. Phys. Chem. B 114 (2010) 12754 .

[108] L. Wang, D.H. Waldeck, J. Phys. Chem. C 112 (2008) 1351.

[109] S. Monari, A. Ranieri, G. Di Rocco, G. van der Zwan, S. Peressini, C. Tavagnacco, D. Millo, M. Borsari, J. Appl. Electrochem. 39 (2009) 2181.

[110] S. Monari, D. Millo, A. Ranieri, G. Di Rocco, G. van der Zwan, C. Gooijer, S. Peressini, C. Tavagnacco, P. Hildebrandt, M. Borsari, J. Biol. Inorg. Chem. 15 (2010) 1233.

[111] S. Monari, A. Ranieri, C.A. Bortolotti, S. Peressini, C. Tavagnacco, M. Borsari, Electrochim. Acta 56 (2011) 6925.

[112] G. Herzog, P. Eichelmann-Daly, D.W.M. Arrigan, Electrochem. Commun. 12 (2010) 335.

[113] G. Herzog, M.T. Nolan, D.W.M. Arrigan, Electrochem. Commun. 13 (2011) 723. 
[114] N.J. Yang, R. Hoffmann, W. Smirnov, A. Kriele, C.E. Nebel, Electrochem. Commun. 12 (2010) 1218.

[115] X.J. Zhao, Z.B. Mai, Z. Dai, X.Y. Zou, Electroanalysis (NY) 22 (2010) 2277

[116] X.J. Zhao, Z.B. Mai, Z. Dai, X.Y. Zou, Talanta 84 (2011) 148.

[117] Q. Shao, P. Wu, P.A. Gu, X.Q. Xu, H. Zhang, C.X. Cai, J. Phys. Chem. B 115 (2011) 8627.

[118] Y.H. Ding, Y. Shu, L.L. Ge, R. Guo, Colloids Surf., A 298 (2007) 163.

[119] H. Wu, P. Wang, X. Hu, Z. Dai, X.Y. Zou, Talanta 84 (2011) 881.

[120] W.J. Zhang, C.H. Fan, Y.T. Sun, G.X. Li, Biochim. Biophys. Acta, General Subjects 1623 (2003) 29.

[121] A. Das, S.A. Trammell, M.H. Hecht, Biophys. Chem. 123 (2006) 102.

[122] S. Rezaei-Zarchi, A.A. Saboury, P. Norouzi, J. Hong, S. Ahmadian, M.R. Ganjali, A.A. Moosavi-Movahedi, A.B. Moghaddam, A. Javed, J. Appl. Electrochem. 37 (2007) 1021.

[123] H. Zhou, Y. Xu, T. Chen, I. Suzuki, G.X. Li, Anal. Sci. 22 (2006) 337.

[124] H. Heli, N. Sattarahmady, A. Jabbari, A.A. Moosavi-Movahedi, G.H. Hakimelahi, F.Y. Tsai, J. Electroanal. Chem. 610 (2007) 67.

[125] Y.Y. Zhang, M.L. Wang, Q.J. Xie, X.H. Wen, S.Z. Yao, Sens. Actuators, B 105 (2005) 454.

[126] S. Haddad, S.M. Derkaoui, T. Avramoglou, E. Ait, A. Othmane, L. Mora, Talanta 85 (2011) 927.

[127] M.R. Ganjali, F. Faridbod, A.A. Saboury, N. Davarkhah, A. Divsalar, G.R. Behbehani, P. Norouzi, Int. J. Electrochem. Sci. 5 (2010) 630.

[128] D.E. Benson, D.W. Conrad, R.M. de Lorimer, S.A. Trammell, H.W. Hellinga, Science (Washington DC) 293 (2001) 1641.

[129] I.L. Medintz, J.R. Deschamps, Curr. Opin. Biotechnol. 17 (2006) 17.

[130] J.A. Hamilton, Prog. Lipids Res. 43 (2004) 177.

[131] J.K. Choi, J. Ho, S. Curry, D.H. Qin, R. Bittman, J.A. Hamilton, J. Lipid Res. 43 (2002) 1000.

[132] S. Curry, P. Brick, N.P. Franks, Biochim. Biophys. Acta, Mol. Cell. Biol. L 1441 (1999) 131.

[133] J.R. Simard, P.A. Zunszain, J.A. Hamilton, S. Curry, J. Mol. Biol. 361 (2006) 336.

[134] J.R. Simard, P.A. Zunszain, C.E. Ha, J.S. Yang, N.V. Bhagavan, I. Petitpas, S. Curry, J.A. Hamilton, Proc. Natl. Acad. Sci. USA 102 (2005) 17958.

[135] B.S. Berlett, E.R. Stadtman, J. Biol. Chem. 272 (1997) 20313.

[136] U. Tornvall, Anal. Methods (UK) 2 (2010) 1638.

[137] T. DiMarco, C. Giulivi, Mass Spectrom. Rev. 26 (2007) 108.

[138] M.G. Espey, S. Xavier, D.D. Thomas, K.M. Miranda, D.A. Wink, Proc. Natl. Acad. Sci. USA 99 (2002) 3481.

[139] A. Tsourkas, G. Newton, J.M. Perez, J.P. Basilion, R. Weissleder, Anal. Chem. 77 (2005) 2862.

[140] F. Rusmini, Z.Y. Zhong, J. Feijen, Biomacromolecules 8 (2007) 1775 .

[141] C.L. Bian, H.Y. Xiong, X.H. Zhang, W. Wen, S.F. Wang, Biosens. Bioelectron. 28 (2011) 216.

[142] B.T. Houseman, J.H. Huh, S.J. Kron, M. Mrksich, Nat. Biotechnol. 20 (2002) 270.

[143] H. Otto, M. Dreger, L. Bengtsson, F. Hucho, Eur. J. Biochem. 268 (2001) 420.

[144] J.D. Dunn, G.E. Reid, M.L. Bruening, Mass Spectrom. Rev. 29 (2010) 29.

[145] M.D. Allen, L.M. DiPilato, M. Rahdar, Y.R. Ren, C. Chong, J.O. Liu, J. Zhang, ACS Chem. Biol. 1 (2006) 371.
[146] T. Mori, K. Inamori, Y. Inoue, X. Han, G. Yamanouchi, T. Niidome, Y. Katayama, Anal. Biochem. 375 (2008) 223.

[147] K.D. Green, M.K.H. Pflum, J. Am. Chem. Soc. 129 (2007) 10.

[148] K. Kerman, H. Song, J.S. Duncan, D.W. Litchfield, H.B. Kraatz, Anal. Chem. 80 (2008) 9395.

[149] S. Martic, M. Labib, H.B. Kraatz, Analyst (Cambridge UK) 136 (2011) 107.

[150] S. Martic, M.K. Rains, D. Freeman, H.B. Kraatz, Bioconjugate Chem. 22 (2011) 1663.

[151] S. Martic, M. Labib, D. Freeman, H.B. Kraatz, Chem. Eur. J. 17 (2011) 6744.

[152] K. Kerman, H.B. Kraatz, Biosens. Bioelectron. 24 (2009) 1484.

[153] S.J. Xu, Y. Liu, T.H. Wang, J.H. Lit, Anal. Chem. 82 (2010) 9566.

[154] J. Ji, H. Yang, Y. Liu, H. Chen, J.L. Kong, B.H. Liu, Chem. Commun. (2009) 1508.

[155] X.H. Xu, Z. Nie, J.H. Chen, Y.C. Fu, W. Li, Q.P. Shen, S.Z. Yao, Chem. Commun. (2009) 6946.

[156] A. Wieckowska, D. Li, R. Gill, I. Willner, Chem. Commun. (2008) 2376.

[157] O.I. Wilner, C. Guidotti, A. Wieckowska, R. Gill, I. Willner, Chem. Eur. J. 14 (2008) 7774.

[158] E. Snir, J. Joore, P. Timmerman, S, Yitzchaik, Langmuir 27 (2011) 11212.

[159] M.Y. Wei, S.D. Wen, X.Q. Yang, L.H. Guo, Biosens. Bioelectron. 24 (2009) 2909.

[160] M.D. Haskell, J.K. Slack, J.T. Parsons, S.J. Parsons, Chem. Rev. 101 (2001) 2425.

[161] K. Burkhard, S. Smith, R. Deshmukh, A.D. MacKerell, P. Shapiro, Curr. Topics Med. Chem. 9 (2009) 678.

[162] H.Y. Chen, H.X. Ju, Y.G. Xun, Anal. Chem. 66 (1994) 4538.

[163] M.C. Liu, G.Y. Shi, L. Zhang, Y.X. Cheng, L.T. Jin, Electrochem. Commun. 8 (2006) 305.

[164] I. Weinryb, R.F. Steiner, Biochemistry 7 (1968) 2488.

[165] M. Zivanovic, M. Aleksic, V. Ostatna, T. Doneux, E. Palecek, Electroanalysis (NY) 22 (2010) 2064.

[166] E. Palecek, V. Ostatna, H. Cernocka, A.C. Joerger, A.R. Fersht, J. Am. Chem. Soc. 133 (2011) 7190.

[167] V. Ostatna, H. Cernocka, E. Palecek, J. Am. Chem. Soc. 132 (2010) 9408.

[168] V. Dorcak, E. Palecek, Anal. Chem. 81 (2009) 1543.

[169] T. Doneux, V. Dorcak, E. Palecek, Langmuir 26 (2010) 1347.

[170] M. Bartosik, V. Ostatna, E. Palecek, Bioelectrochemistry 76 (2009) 70

[171] P. Juskova, V. Ostatna, E. Palecek, F. Foret, Anal. Chem. 82 (2010) 2690.

[172] S.M. Chen, J.Y. Chen, R. Thangannithu, Electroanalysis (NY) 20 (2008) 1565.

[173] H.H. Cai, X. Zhong, P.H. Yang, W. Wei, J.N. Chen, J.Y. Cai, Colloids Surf., A 372 (2010) 35.

[174] N. Hui, J.S. Wang, W. Sun, Electroanalysis (NY) 22 (2010) 536.

[175] J. Wang, M. Shen, Y. Cao, G.X. Li, Biosens. Bioelectron. 26 (2010) 638.

[176] K. Pinwattana, J. Wang, C.T. Lin, H. Wu, D. Du, Y.H. Lin, O. Chailapakul, Biosens. Bioelectron. 26 (2010) 1109.

[177] J. Wang, Y. Cao, Y. Li, Z.Q. Liang, G.X. Li, J. Electroanal. Chem. 656 (2011) 274.

[178] D. Du, L.M. Wang, Y.Y. Shao, J. Wang, M.H. Engelhard, Y.H. Lin, Anal. Chem. 83 (2011) 746.

[179] D. Du, J. Wang, D.L. Lu, A. Dohnalkova, Y.H. Lin, Anal. Chem. 83 (2011) 6580. 